\title{
Criminal Convictions and Risk Taking
}

\author{
Eli Amir \\ Tel Aviv University and City University of London \\ eliamir@post.tau.ac.il \\ Juha-Pekka Kallunki* \\ University of Oulu, Department of Accounting \\ Juha-Pekka.Kallunki@oulu.fi \\ Henrik Nilsson \\ Stockholm School of Economics \\ Henrik.Nilsson@hhs.se
}

1 July 2013

\begin{abstract}
An analysis of a proprietary dataset reveals that non-trivial proportions of directors, CEOs and CFOs in Swedish listed companies have been convicted or suspected of crimes. Based on prior literature, we argue that directors and senior executives who have been convicted or suspected of crimes are more prone to take risk. Consistent with this argument, we find that firms with more criminally convicted/suspected directors and CEOs report more volatile earnings, engage more in goodwill writeoffs due to more unsuccessful acquisitions, and recognize bad news in earnings in a less timely manner. We also find that these firms are, on average, smaller and less profitable. These findings highlight the role personal characteristics of directors and senior management play in managerial decisions.
\end{abstract}

JEL Classification: M41, G10, G30, K42

Keywords: Criminal convictions, Earnings volatility, Profitability, Acquisitions, Directors, Executives, Accounting conservatism, Goodwill writeoffs.

We would like to thank Jeroen Derwall, Lars Hassel, Celia Moore, Per Olsson, Markku Rahiala, Petri Sahlström, Carmit Tadmor, and seminar participants at Bocconi (Italy), University of Cyprus (Cyprus), University of Gothenburg (Sweden), Helsinki School of Economics (Finland), University of Oulu (Finland), Penn State University (USA), Stockholm School of Economics (Sweden), Tel Aviv University (Israel), and the Umeå School of Business (Sweden) for many useful comments. We gratefully acknowledge financial support from Mistra and NASDAQ-OMX. The study has been evaluated and approved by The Regional Ethical Review Board in Umeå, Sweden (DNR 08:074 Ö). 


\section{Criminal Convictions and Risk Taking}

\section{Introduction}

Corporate decisions may vary not only with firm characteristics and the structure of governance mechanisms, but also with the personal characteristics and psychology of directors and senior executives. ${ }^{1}$ This study examines whether firms with larger proportions of directors who have either been convicted of a crime or have been suspected of serious crimes, and firms with Chief Executive Officers (CEOs) and/or Chief Financial Officers (CFOs) who have been convicted/suspected of crimes are more likely to engage in risky activities.

Based on prior studies, we argue that individuals who have been convicted/suspected of crimes take more risk. We predict that companies led by convicted/suspected directors, CEOs and CFOs will engage more in risky activities, leading to more volatile earnings. We also predict that these companies will engage in more risky acquisitions, leading to more frequent and larger goodwill writeoffs due to more dispersed outcomes. In addition, we expect these companies to report less conservatively, as less conservative financial reporting is itself more risky to the firm due to the increased exposure to litigation and regulatory intervention.

Our analysis employs a database on the criminal convictions of all directors, CEOs and CFOs appointed by Swedish listed firms. The database was obtained from the Swedish National Council for Crime Prevention and it contains all criminal convictions in Sweden since 1974, regardless of the type of crime or whether these convictions have been expunged from the official crime records. Specifically, $23 \%$ of directors and senior executives (987 out of 4,317 ) have been convicted of a crime, a proportion similar to that of convictions in the

\footnotetext{
${ }^{1}$ Prior studies have found that management-specific effects are linked to corporate decisions. See for instance Dyreng et al. (2010) in the case of tax avoidance, and Bamber et al. (2010) in the case of corporate disclosure.
} 
entire Swedish population (Svensson, 2000). These statistics suggest that criminal convictions of directors and senior executives are not isolated events, thereby supporting the use of intensity of criminal activity as a measure of individuals' propensity to take risks. ${ }^{2}$

We begin by documenting the extent of criminal convictions of directors, CEOs and CFOs in Swedish listed companies. ${ }^{3}$ We show that out of 3,373 directors, 727 (21.6\%) have been convicted of a crime; 128 additional directors (4.0\%) have been investigated for serious crimes but not convicted. Also, out of 580 CEOs, 182 (31.3\%) have been convicted and 25 (4.3\%) suspected of a serious crime; out of 364 CFOs, $78(21.4 \%)$ have been convicted and $11(3 \%)$ suspected of a serious crime. We also find some evidence suggesting that companies with weaker corporate governance are more likely to have convicted/suspected CEOs and higher proportions of convicted/suspected directors.

Presumably, having been convicted/suspected of a crime reflects an undesirable personal attribute, which raises the question why individuals with criminal convictions or suspected of serious crimes are appointed to senior managerial positions. Discussions with several listed firms and head-hunters assisting firms in recruiting senior management suggest that criminal records are rarely examined during the selection process. Hence, individuals with criminal convictions can be appointed as directors and senior executives, because these convictions are often not known. Also, many of the convictions relate to serious traffic violations (for instance, drunk driving), which are not associated with corruption the way fraud and robbery might be viewed, and hence are more likely to be overlooked by the appointing firm.

\footnotetext{
2 These and other related figures in this study do not include speeding, parking and similar minor infringements of traffic laws. The dataset contains criminal convictions in a court of law.

${ }^{3}$ During the sample period, 24 Swedish firms were listed on the New York Stock Exchange and NASDAQ in addition to their listing in Sweden. The proportions of convicted directors and senior executives in these companies are similar to those of Swedish companies listed only in Sweden. While ideally we would need more data on US companies for a more meaningful comparison, this finding suggests that having convicted directors and senior executives is a phenomenon not confined to Sweden, as foreign firms listed in US stock markets must adhere to US laws and regulation.
} 
We continue with an analysis of the association between criminal activity of directors, CEOs and CFOs and earnings volatility. We find a positive association between the proportion of convicted/suspected directors and earnings volatility. We also find such an association for CEOs, but not for CFOs. This result supports the argument that companies led by directors and CEOs with criminal convictions engage in more risky activities.

We also examine the association between directors', CEOs' and CFOs' criminal history and the frequency and magnitude of goodwill writeoffs. We focus on goodwill writeoffs because goodwill must be assessed for impairment annually, and writeoffs are more likely to occur in risky acquisitions where subsidiary performance is more dispersed, a reflection of the propensity of management to acquire more risky businesses. The evidence suggests that the frequency and magnitude of goodwill writeoffs is significantly larger in companies led by criminally convicted/suspected directors and CEOs; we do not find any link between goodwill writeoffs and crime convictions for CFOs, perhaps because CFOs have less of a say than directors and CEOs in acquisition-related decisions. In addition, we find that goodwill writeoffs are more likely to occur when the proportion of convicted/suspected directors declines and when a convicted/suspected CEO is replaced by a "clean" CEO. This result suggests that incoming directors and CEOs prefer to write off recognized goodwill from past high-risk acquisitions made by former directors and CEOs, providing additional support for the argument that firms led by convicted/suspected directors and CEOs engage in more risky acquisitions.

Recognition of goodwill writeoffs may indicate conservative accounting; but only if these writeoffs are recognized in a timely manner. In addition, less conservative reporting exposes companies to litigation and regulatory intervention and limits their ability to obtain external funding. We therefore examine the timeliness of recognizing bad news in earnings using Basu's (1997) model. We find that companies with criminally convicted/suspected 
directors and CEOs do not recognize bad news in a timely manner, while companies without convicted/suspected directors and CEOs exhibit conservative reporting. This result suggests that goodwill writeoffs recognized by firms with convicted/suspected directors and CEOs reflect unsuccessful acquisitions rather than timely recognition of bad news. It also suggests that companies led by directors and CEOs convicted/suspected of criminal activities assume additional risk due to less conservative reporting.

Overall, our results suggest that companies led by directors and CEOs who have been convicted/suspected of crimes take more risk, as reflected by more volatile earnings, more unsuccessful acquisitions, and less conservative reporting. The effect on corporate risk is strongest for directors, somewhat weaker for CEOs and diminishes for CFOs.

Our study contributes to the literature in three dimensions. First, we link criminal history to earnings volatility and to corporate decisions such as acquisitions and reporting conservatism. While prior studies have used criminal behavior, such as traffic violations, to measure individual investors' propensity to take risks (Grinblatt and Keloharju, 2009), we use convictions and suspicions of criminal activities to document the association between managerial risk taking and corporate decisions. Second, our dataset allows us to jointly examine the link between criminal history and corporate risk taking for board members and senior executives. Finally, we add to the literature on the association between the CEO's personal attributes and the success of acquisitions and subsequent goodwill writeoffs (see Malmendier and Tate, 2008; and Cain and McKeon, 2012).

The main limitation of this study is that we are unable to establish whether criminally convicted/suspected directors and senior executives cause companies to take more risk or whether companies with a certain organizational culture are more likely to employ convicted/suspected directors and senior executives. Still, the findings of this study are important to equity investors and lenders who are interested in assessing the overall risk of 
the firm, and in particular, the link between corporate leaders' personal psychology and risk taking.

\section{Literature Review and Institutional Background}

\subsection{Criminal Convictions and Risk-Taking Behavior}

The extant literature has established the link between an individual's criminal behavior and his/her propensity to take risks. Economic theories on crime have argued that a decision to engage in criminal activities can be seen as rational behavior under uncertainty. In particular, Becker (1968) and Ehrlich (1973) argue that individuals engage in criminal acts if the expected gain from that act is greater than the expected costs. An important implication of these theories is that a risk-neutral individual will spend more time on illegal activities relative to a risk-avoider, and a risk-seeker will spend more time on such activities relative to both (Ehrlich, 1973). While it is widely accepted that criminal convictions reflect an individual's propensity to take risk, these early theories assume that all individuals have the same personal attributes, values and norms.

More recent research has linked crime to specific personal attributes underlying the risk-seeking behavior. By recognizing the role of personal attributes, this research points out that criminal and other unethical behavior often reflects an individual's overconfident, narcissistic or sensation-seeking behavior. In particular, individuals who engage in criminal activities underestimate the probability of negative outcomes (see Eide et al., 2006; Garoupa, 2003; Palmer and Hollin, 2004; Walters, 2009). Overconfidence is also a major determinant of traffic accidents (Sandroni and Squintani, 2004). Blickle et al. (2006) find that low behavioral self-control, high hedonism and high narcissism are positively related to the likelihood of committing business white-collar crime. Finally, sensation-seekers take greater risks while driving (Iversen and Rundmo, 2002). 
Prior studies also imply that personal attributes reflected in criminal behavior (overconfidence, sensation-seeking and narcissism) also explain managerial decisions and resulting corporate outcomes. Many of these studies focus on CEO personal attributes. For instance, Malmendier and Tate (2008) find that overconfident CEOs are more likely to engage in value-destroying mergers and acquisitions (M\&A). Cain and McKeon (2012) focus on sensation seeking and argue that sensation-seeking CEOs engage in more frequent M\&A activity. Aktas et al. (2010) find that CEO narcissism in both the acquirer and target companies has a negative effect on the takeover process. Hambrick and Mason's (1984) “Upper Echelons Theory" argues that managers' experiences, values and honesty affect their choices and consequent corporate decisions. Libby and Rennekamp (2012) find that managerial overconfidence contributes to the decision to issue management forecasts. Amir et al. (2012) find that audit partners with criminal convictions are more likely to engage in more risky audits. Results from these studies support the view that directors' and senior executives' personal propensity to take risk, as reflected by their criminal convictions, are related to business decisions, and in particular, to corporate risk taking.

Following the above literature, we use personal criminal convictions as a proxy for a higher propensity to take risk. In particular, we expect companies led by directors and senior executives with criminal convictions to engage more in risky activities, leading to more volatile earnings and more unsuccessful acquisitions. In addition, prior studies argue that firms adopt conservative accounting to reduce litigation risk and regulatory intervention (Qiang, 2007). If the propensity to assume (litigation) risk is higher in companies with more directors and senior executives with criminal convictions, we would expect these companies to report less conservatively. To address this issue, we adopt the Basu (1997) model of conditional conservatism. 


\subsection{Institutional Background}

Information on criminal convictions in Sweden is maintained by the police. Typically, a personal criminal record may be accessed by the person involved but not by the public. Criminal background checks are required for positions involving contacts with minors, for certain health services occupations, and employment with firms providing security services (Stoll and Bushway, 2008). An important limitation of these official crime registers is that they include only convictions not yet expunged. Depending on the seriousness of the crime, convictions are expunged from these databases after 5-10 years. Hence, official registers contain only part of all crime convictions that are relevant for assessing an individual's personal attributes.

Prior crime convictions are often considered an undesirable personal attribute. ${ }^{4}$ Still, a non-trivial proportion of directors and senior executives have been convicted of a serious crime. Since Swedish citizens may request a transcript of their own record, Swedish companies could require a criminal record check on candidates for board membership or other senior appointments. Similarly, US candidates can obtain such transcripts from the government. Informal discussions with listed firms and head-hunters assisting firms in the process of recruiting board members indicate that this policy is uncommon in both Sweden and in the US. Also, the process of selecting directors is quicker and less formal than that of selecting senior corporate executives. Usually, the names of potential board member candidates are put forward by the firm's nomination committee and the head-hunters rarely examine these candidates in depth. An examination of criminal records is not part of the selection process. Consequently, convicted individuals can be appointed as directors and

\footnotetext{
4 The crime convictions in our sample occurred before the board member or the senior executive were employed by the firm. Searching the media, we found four cases where directors' crime convictions became publicly known. In all cases, the convicted directors had to resign their position. This anecdotal evidence suggests that crime convictions are considered a negative personal attribute.
} 
senior executives, because the convictions are often not known to the nomination committee or shareholders.

The process of appointing directors, CEOs and CFOs in Sweden is similar in many respects to that in the US. However, there are some differences that are likely to make it more stringent in Sweden than in the US. In particular, the nomination committee for directors in Sweden is not made up of board members, but of shareholders' representatives who nominate new candidates to the shareholders' meeting. Second, CEOs and other senior executives are not involved in appointing directors. Appendix A provides a short summary of the Swedish system of justice and the Corporate Governance Code.

Another likely reason for appointing individuals with criminal convictions as directors and senior executives is that many of these convictions are linked to crimes that are not viewed by many as impairing an individual's ability to exercise sound business judgment. However, the criminology literature shows that criminal convictions, regardless of the nature or seriousness of the crime, are indicative of an individual's overconfidence and tendency to take risks. Appointing such individuals to senior corporate positions is likely to increase overall risk.

Prior studies also suggest that appointing individuals with criminal tendencies to senior managerial positions may be common. For instance, Pech and Slade (2007) argue that firms sometimes appoint and promote to top managerial positions individuals who may be incompetent, narcissistic and manipulative. They conclude that such individuals can be characterized as organizational sociopaths, and they are sometimes promoted repeatedly until they reach the highest levels of the organizational hierarchy. In addition, Jones et al. (2004) suggest that organizational cultures actually tolerate and favor manipulative, egotistical and self-centered managerial behavior, personal traits that are often found among individuals with criminal convictions. Also, Hvide (2002) uses tournament theory to show 
that an equilibrium with excessive risk-taking combined with low effort levels can sustain. Therefore, if individuals with criminal convictions are more likely to take excessive risks, it is not surprising to see them appointed to leadership positions in the organization.

\section{Data and Variables}

\subsection{Data Sources}

The initial sample includes all 605 industrial companies listed on the Swedish stock market for the period 1999-2007 and monitored by Finansinspektionen - the Swedish securities regulator. The sample period is limited to 1999-2007 due to data availability. We removed financial institutions because these companies are subject to a more restrictive regulatory environment and their financial statements are largely incompatible with those of industrial companies. To compute our variables, we need current and lagged financial data, which reduced our sample to 348 companies. We also removed observations for which the financial variables were above (below) the $99^{\text {th }}\left(1^{\text {st }}\right)$ percentile of the distribution. This process resulted in removing 14 firms (148 observations) as outliers. The final sample consists of 334 companies (1,754 firm-year observations). Table 1 summarizes the sample selection process.

The identity and social security numbers of directors and senior executives in Swedish companies were obtained from Finansinspektionen. These social security numbers were used to extract information on criminal activities from Brå (The Swedish National Council for Crime Prevention, www.bra.se). This dataset contains information on all crimes committed by Swedish citizens since 1974, regardless of whether the convictions have been expunged from the official crime records. Specifically, it contains information about individuals who have been found guilty in a court of law or received summary punishments by prosecutors. The information contained in the database is collected from all Swedish courts and 
prosecution authorities. For each registered director/CEO/CFO, this dataset includes details of the crime (an exact reference to the law violated) and the punishment (the length of unconditional prison sentences, suspended sentences and monetary fines). The database does not, however, contain information on minor offences, such as speeding, parking and violations of local bylaws.

While criminal convictions are undoubtedly evidence of criminal behavior, focusing only on actual convictions could potentially cause a selection bias. This is because the burden of proof beyond any reasonable doubt is heavier in more serious crimes. Consequently, serious crimes are likely to be underrepresented in the dataset of actual criminal convictions. This selection bias could be reduced by including data on individuals suspected but not convicted of serious crimes, as suggested by Korsell (2001). Our dataset contains information on all Swedish citizens suspected of serious crimes for which the penalty is prison. Suspicion of a crime in this study means that a police investigation was launched, but the prosecutor later on decided not to pursue the case in court or lost the case in court. ${ }^{5}$

Appendix B includes a summary of the crimes included in this study. Many of the convictions in the sample are related to drunk driving and other serious traffic violations. While these crimes may seem harmless to many, prior literature has established a strong link between traffic violations and risk-seeking (Grinblatt and Keloharju, 2009), and between traffic violations and sensation seeking (Iversen and Rundmo, 2002). ${ }^{6}$

Accounting and market data for Swedish listed firms were obtained from Thomson's Datastream. If the firm was missing from Thomson's Datastream, we retrieved data from the

\footnotetext{
5 The database is maintained by the National Police Board and is mainly used by the Police, Tax Authorities, Customs and Coastguard to coordinate preliminary investigations and crime prevention.

${ }^{6}$ We estimated our models separately for a sub-sample of traffic-related convictions and a sub-sample of all other convictions. The results are very similar across these sub-samples.
} 
Bureau van Dijk global database, accessed via the Wharton Research Data Services (WRDS), and the Six Trust database.

\subsection{Variable Definitions}

We construct three crime-related variables: (i) $B O A R D_{i t}$ is the proportion of convicted/ suspected directors out of the total number of directors for firm $i$ at fiscal year-end $t$; (ii) $C E O_{i t}$ is an indicator variable equal to " 1 " if firm $i$ 's CEO has been convicted/suspected of a crime at fiscal year-end $t$, and " 0 " otherwise; and (iii) $C F O_{i t}$ is an indicator variable that obtains the value of " 1 " if firm $i$ 's CFO has been convicted/suspected of a crime at fiscal year-end $t$, and " 0 " otherwise.

We measure earnings volatility in two ways: The first one is the absolute value of annual earnings changes divided by market value of equity at the beginning of the year $\left(A B S E C_{i t}\right)$. The second one is the standard deviation of earnings scaled by total assets $\left(E V O L_{i t}\right)$. While the first measure of earnings volatility can be constructed for each firm/year, we can only obtain one observation of $E V O L_{i}$ per firm over the sample period. Earnings $\left(E P_{i t}\right)$ are measured as earnings per share divided by the share price at the beginning of the year.

The effect of goodwill writeoff is measured in two ways: $W O_{i t}$ is an indicator variable that obtains the value of " 1 " if the firm recognized a goodwill writeoff in year $t$, and " 0 " otherwise; and WO/GOODWILL $L_{i t}$, is the goodwill writeoff divided by the amount of goodwill before the writeoff (the proportion of goodwill written off). Annual stock returns for each firm-year are computed from January to December $\left(R E T_{i t}\right)$. Operating accruals $\left(\mathrm{OPACC}_{\mathrm{it}}\right)$ is measured as follows:

$$
\begin{aligned}
& \text { OPACC }_{i t}=\Delta \text { Inventory }_{i t}+\Delta \operatorname{Re} \text { cievables }_{i t}+\Delta \text { Other } \text { current assets }_{i t} \\
& -\Delta \text { Payables }_{i t}-\Delta \text { Other current liabilities }{ }_{i t}-\text { Depreciation }_{i t}
\end{aligned}
$$


We also use three risk measures as control variables in our tests. Firm size $\left(S I Z E_{i t}\right)$ is the natural logarithm of total assets; financial leverage $\left(L E V E R A G E_{i t}\right)$ is measured as interest-bearing debt divided by total assets; the market-to-book ratio $\left(P B_{i t}\right)$ is measured as the market value of equity divided by the book value of equity.

\subsection{Descriptive Statistics}

The mean, median, and standard deviation of the number of directors serving on Swedish listed firms is $8.36,7$ and 3.42 , respectively. The mean number of directors serving on our sample firms is slightly lower, 7.66, with a median of 7 directors and standard deviation of 3.07. Overall, the size of boards in our sample is not materially different than that of an average listed firm in Sweden. Also, 102 firms in our sample have five or less directors on the board; the CEO is a member of the board in 42 of these firms $(41 \%)$. The remaining firms have more than five directors on the board; the CEO is a board member in 101 of these firms $(44 \%)$.

Table 2, Panel A, presents information on the number of convicted/suspected directors, CEOs, CFOs and block-holders of $10 \%$ or more of the shares in all Swedish listed firms. A quarter of board members have been either convicted or suspected of a crime. Also, 35.7\% of CEOs and $24.5 \%$ of CFOs have been convicted or suspected of a crime. Finally, $44.2 \%$ of block holders have been either convicted or suspected of crimes.

Panel B of Table 2 presents the distribution of the three crime variables in our sample. The evidence suggests that $30 \%$ of board members, on average, have criminal convictions or have been suspected of crime. The indicator variables (CEO and $C F O$ ) suggest that $34 \%$ and $17 \%$ of CEOs and CFOs have criminal convictions or have been suspected of a crime, respectively. The proportion of convicted/suspected CFOs is smaller (at the 0.01 level) than 
that of convicted/ suspected CEOs, probably because many CFOs are licensed accountants or certified auditors who are under greater scrutiny when obtaining their certification.

Panel $\mathrm{C}$ of Table 2 presents the distribution of the crime variables by industry using the Fama and French 5-Industry classifications. The sample includes primarily retail, service and manufacturing companies with little representation for high-tech and high R\&D companies. The proportions of convicted directors and senior executives are similar across industries FF1, FF2 and FF5 (more than 95\% of the sample).

Panel D presents pair-wise correlations between the crime variables and selected variables. Several correlations are worth noting: The proportion of convicted/suspected board members decreases with the size of the board, as reflected by the negative correlation between BOARD and BOARDSIZE (Pearson $=-0.19$, Spearman $=-0.18$ ). The likelihood of having a convicted/suspected CEO increases with the proportion of convicted board members as reflected by the positive correlation between BOARD and $C E O$ (Pearson $=0.22$, Spearman $=0.21)$. The size of the firms $($ SIZE $)$ and the size of the board $($ BOARDSIZE $)$ are positively correlated $($ Pearson $=0.59$, Spearman $=0.60)$. Finally, block-holders of $10 \%$ or more of the shares are less frequent in large firms, as reflected by the negative correlation between BLOCKHOLDER and SIZE (Pearson $=-0.28$, Pearson $=-0.26)$.

Table 3 presents summary statistics and univariate tests for several firm-specific variables. For each of the three crime variables (BOARD, CEO and $C F O)$, we divide our sample into two subsamples. For directors, we divide the sample into a subsample of companies with more (less) than $50 \%$ directors who have been convicted/suspected of a crime. We choose $50 \%$ as a cut-off because it represents a majority of directors in board meetings. For CEOs and CFOs we divide the sample into subsamples of companies with and without convicted/suspected CEOs and CFOs, respectively. 
As the table shows, companies with more than $50 \%$ convicted/suspected directors report more volatile earnings (at the 0.01 level for both ABSEC and EVOL) than companies with less than $50 \%$ convicted/suspected directors. In addition, companies with more convicted/suspected directors recognize more frequent and larger goodwill writeoffs, though the difference between the two subsamples is not significant at the 0.10 level. These companies also report lower earnings (at the 0.01 level), and lower operating accruals (at the 0.01 level). In addition, these companies are relatively smaller (at the 0.01 level). Finally, leverage and market-to-book ratios are similar across the two subsamples. Overall, these results support the claim that companies with more convicted/suspected directors are riskier in that they have greater earnings volatility and are smaller in size. The finding that earnings are lower, on average, for companies with more convicted/suspected directors indicates that the greater earnings volatility of these companies is not an artifact of higher earnings. Moreover, this result could also be interpreted as reflecting higher risk, as this variable is the inverse price-earnings ratio.

Turning to CEOs, earnings are more volatile in companies with convicted/suspected CEOs (at the 0.05 level or better), suggesting that companies with convicted/ suspected CEOs take more risks. Moreover, the frequency and magnitude of goodwill writeoffs is significantly larger in companies with convicted/suspected CEOs. Also, mean earnings of companies with convicted/ suspected CEOs are lower at the 0.05 level, but the median earnings are similar across the two subsamples. All remaining variables are not materially different across the two subsamples.

Univariate results are somewhat surprising for CFOs: Median standard deviation of earnings is lower (at the 0.01 level) and median earnings are higher (at the 0.01 level) for companies with convicted/suspected CFOs. However, these results do not hold for the mean variables. Furthermore, companies with convicted/suspected CFOs are larger (at the 0.01 
level) and more highly leveraged (at the 0.01 level) than those without convicted/suspected CFOs. Overall, except for the higher leverage ratio, there is no consistent evidence that companies with convicted/suspected CFOs take more risks. ${ }^{7}$

\subsection{Determinants of the Proportion of Directors and Senior Executives with Criminal}

\section{Records}

What are the determinants of the proportions of criminally convicted/suspected directors and the likelihood of convicted/suspected CEOs and CFOs? Absent any clear guidance in the literature on this issue, we have constructed a model relying on the corporate governance literature. We estimate regressions separately for directors (using OLS), CEOs and CFOs (using logistic regressions). For board members, the model is as follows (for CEOs and CFOs the dependent variables and the first two explanatory variables are adjusted accordingly):

$$
\begin{aligned}
& \text { BOARD }_{i t}=\alpha_{0}+\sum_{s=1999}^{2007} \alpha_{s} \text { YEAR }_{s}+\sum_{i=1}^{I} \alpha_{i} \text { FIRM }_{i}+\beta_{1} C E O_{i t}+\beta_{2} \text { CFO }_{i t}+\beta_{3} \text { MALE }_{i t}+ \\
& \beta_{4} \text { BUSY }_{i t}+\beta_{5} \text { CEODUAL }_{i t}+\beta_{6} \text { BOARDSIZE }_{i t}+\beta_{7} \text { BLOCKHOLD }_{i t}+\beta_{8} \text { EMPLOYEE }_{i t} \\
& +\beta_{9} A G E_{i t}+\beta_{10} \text { LEVERAGE }_{i t}+\beta_{11} \text { SIZE }_{i t}+\beta_{12} \text { PB }_{i t}+\varepsilon_{i t}
\end{aligned}
$$

The dependent variable in Equation (1) is the proportion of convicted/suspected directors. On the right-hand side of the model, we include two variables that indicate whether the CEO or the CFO have been convicted/suspected of a crime. We expect that firms with convicted/suspected senior executives have higher proportions of convicted/ suspected directors; hence, we expect the coefficients $\beta_{1}$ and $\beta_{2}$ to be positive.

\footnotetext{
${ }^{7}$ We identified 490 observations with a convicted/suspected CEO and a "clean" CFO, and 208 observations with a convicted/suspected CFO and a "clean" CEO. We find that companies with a convicted/suspected CEO and a "clean" CFO are smaller (at the 0.01 level) and report lower and more volatile earnings (at the 0.05 level), than companies with a "clean" CEO and a convicted/suspected CFO. Overall, our evidence suggests that the impact of the CFO on firm risk is immaterial.
} 
The model includes seven variables that have been identified in prior studies to be associated with the level of corporate governance (see Larcker et al., 2007). We expect these variables to be associated with the dependent variable: higher proportions of convicted/ suspected directors and the existence of a convicted/suspected CEO or CFO will result in weaker governance.

We include $M A L E_{i t}$ (the proportion of male board members) in the model because prior studies (Daly, 1989; Zahra et al., 2005; and Blickle et al., 2006) argue that males engage in white-collar crimes more than females. In addition, Adams and Ferreira (2009) show that companies with more gender-diverse boards invest more effort in monitoring activities. Hence, we expect $\beta_{3}$ to be positive. We also include $B U S Y_{i t}$ (the proportion of board members with three or more board memberships in the listed Swedish firms) without predicting its sign. While more experienced directors contribute to stronger governance, these directors could be less committed to a company's success. CEODUAL $L_{i t}$ (an indicator variable that obtains the value of " 1 " if the CEO is also a member of the board, and " 0 " otherwise) is included because prior studies have found that when the CEO is on the board, the level of governance is weaker. Hence, $\beta_{5}$ is expected to be positive. BOARDSIZE $E_{i t}$ (the logarithm of the total number of board members) is included because larger boards have been found to be less effective ( $\beta_{6}$ is expected to be positive).

$B L O C K H O L D_{i t}$ is an indicator variable that obtains the value of " 1 " if there is at least one shareholder that owns $10 \%$ or more of the firm's equity, and " 0 " otherwise. If the existence of major shareholders reduces agency costs, $\beta_{7}$ is expected to be negative. We include EMPLOYEE $E_{i t}$ (the proportion of employee representatives on the board) because employee representatives are known to be independent directors, which is likely to reduce the likelihood of appointing criminally convicted/suspected directors and senior executives. Hence, $\beta_{8}$ is expected to be negative as well. $A G E_{i t}$ (the average age of the board members) 
is included as a control variable for directors' experience without predicting the sign of its coefficient $\left(\beta_{9}\right)$.

In addition, we include in the model three variables designed to capture different aspects of firm risk: $L E V E R A G E_{i t}$ (interest-bearing debt divided by total assets) is associated with greater financial risk. We expect that firms with a larger proportion of convicted/ suspected directors are more likely to engage in risky projects and borrow more. On the other hand, firms with more leverage are likely to be under stricter control by lenders, which may reduce the likelihood of appointing criminals as directors and senior executives. Thus, the sign of $\beta_{10}$ depends on the direction of causality. SIZE $E_{i t}$ (the natural logarithm of total assets) is included in the model because larger firms are more visible to the public and decisions, such as appointing directors, CEOs and CFOs, may be under greater public scrutiny, hence reducing the likelihood of appointing criminals ( $\beta_{11}$ is expected to be negative). Finally, we include the market-to-book ratio $\left(P B_{i t}\right)$ as control for the investment opportunity set without predicting the sign of $\beta_{12}$.

Equation (1) includes firm and year fixed-effects to control for potential omitted variables. All $t$-values in the pooled regression are based on heteroskedasticity-adjusted standard errors. Also, we take into account firm-level clustering in standard errors as in Petersen (2009). Specifically, we allow both a firm and time effect in the panel data and address the time effect parametrically by including yearly dummies and then estimate standard errors clustered on the firm dimension.

The results in Table 4 show that, as expected, the proportion of convicted/suspected directors is positively correlated with having a convicted/suspected CEO. This is reflected by the positive coefficient on CEO in the board regression (significant at the 0.10 level), and the positive coefficient on BOARD in the CEO regression (significant at the 0.01 level). Having 
a convicted/suspected CFO is unrelated to having a higher proportion of convicted/suspected directors or to having a convicted/suspected CEO.

The coefficients on $M A L E_{i t}$ are positive, as expected, for board members and CEOs, but significant at the 0.01 level only for board members; this coefficient is negative but not statistically significant in the CFO regression. This result provides some support to the argument that business men are more involved in criminal activities than business women. The coefficient on $B U S Y$ is negative (significant at the 0.10 level) in the CEO regression but positive (at the 0.01 level) in the CFO regression. This result suggests that when the board includes "professional" directors, the likelihood of having a convicted/suspected CEOs decreases, but the likelihood of having a convicted/suspected CFO increases.

The coefficients on CEODUAL in the directors and CEOs regressions are positive, as expected (significant at the 0.10 level for directors), suggesting that when the CEO is also a member of the board, the proportion of convicted/suspected directors increases. However, the coefficient on CEODUAL is negative (at the 0.01 level) in the CFO regression, suggesting that when the CEO is also a member of the board, the likelihood of having a convicted/suspected CFO decreases.

Companies with larger boards are less likely to have a convicted/suspected CEO, as reflected by the negative coefficient on BOARDSIZE in the CEO regression. Also, the coefficient on $B L O C K H O L D_{i t}$ is positive and significant at the 0.01 in the CFO regression, suggesting that the existence of a major shareholder increases the likelihood of having a convicted/suspected CFO. Both of these results seem counter-intuitive as larger boards are often blamed for weaker corporate governance, and having a major shareholder is often linked to improved board-independence. However, as Larcker et al. (2007) point out, corporate governance variables often exhibit conflicting results due to measurement errors. Furthermore, companies with older directors are less likely to have a convicted/suspected 
CEO, but more likely to have a convicted/suspected CFO, as reflected by the negative and positive coefficients on $A G E$ (significant at the 0.05 level) in the $\mathrm{CEO}$ and $\mathrm{CFO}$ regressions, respectively.

The coefficients on $S I Z E_{i t}$ are positive in the CEO and CFO regressions, suggesting that larger firms are more likely to have convicted/suspected senior executives. Again, this result seems counter-intuitive given the higher visibility to regulators of larger corporations. The variables EMPLOYEE, LEVERAGE, and $P B$ exhibit no relation with the dependent variable.

Overall, we find some evidence suggesting that higher proportions of criminally convicted/suspected directors are associated with weaker corporate governance. Regarding CEOs, it seems that the variable that best explains having a convicted/suspected CEO is having larger proportions of convicted/suspected directors. As for CFOs the evidence is inconsistent with weaker corporate governance. Also, having a convicted/suspected CFO is unrelated to having convicted/suspected directors and CEOs.

\section{Empirical results}

\subsection{The Association between Criminal Convictions and Earnings Volatility}

We use the next model to estimate the association between the three crime variables $\left(B O A R D_{i t}, C E O_{i t}, C F O_{i t}\right)$ and earnings volatility. We use the following two models estimated separately for directors, CEOs and CFOs:

$$
\begin{aligned}
& \text { ABSEC }_{i t}=\alpha_{0}+\sum_{s=1999}^{2007} \alpha_{s} \text { YEAR }_{s}+\sum_{i=1}^{I} \alpha_{i} \text { FIRM }_{i}+\gamma_{1} \text { CRIME }_{i t}+\gamma_{2} \text { LEVERAGE }_{i t} \\
& +\gamma_{3} \text { SIZE }_{i t}+\gamma_{4} P B_{i t}+\varepsilon_{i t} \\
& \text { EVOL }_{i}=\alpha_{0}^{\prime}+\gamma_{1}^{\prime} C R I M E_{i t}+\gamma_{2}^{\prime} L^{\prime} E V E R A G E_{i t}+\gamma_{3}^{\prime} \operatorname{SIZE}_{i t}+\gamma_{4}^{\prime} P B_{i t}+\varepsilon_{i t}
\end{aligned}
$$


The dependent variable in Equation (2a) is the absolute value of earnings changes per share divided by lagged share price $\left(A B S E C_{i t}\right)$. The dependent variable in Equation $(2 \mathrm{~b})$ is the standard deviation of earnings deflated by total assets $\left(E V O L_{i}\right)$, which is computed for each firm over the sample period. We expect a positive coefficient on $C R I M E_{i t} \in\left\{B O A R D_{i t}\right.$, $\left.C E O_{i t}, C F O_{i t}\right\}$ in each of the three regressions. Equation (2) also includes three risk measures, financial leverage $\left(L E V E R A G E_{i t}\right)$, firm size $\left(S I Z E_{i t}\right)$, and market-to-book ratios $\left(P B_{i t}\right)$, as controls. We expect a positive coefficient on financial leverage $\left(\gamma_{2}>0\right)$, as higher financial leverage is associated with higher risk. We also expect a negative coefficient on firm size $\left(\gamma_{3}<0\right)$, because larger firms are normally less risky. Consistent with Fama and French (1992), we expect a positive coefficient on market-to-book ratios $\left(\gamma_{4}>0\right)$. Obtaining the expected coefficients on the three control variables will suggest that the dependent variable is indeed associated with risk.

As the dependent variables in Equation (2) are skewed, we estimate the model using rank regressions. Also, Equation (2a) includes fixed year and firm effects. Heteroskedasticity-adjusted standard errors are used to calculate $t$-values, and the firm-level clustering in standard errors is taken into account as described in Petersen (2009). Table 5 presents the results of estimating Equation (2a) in the left panel and Equation (2b) in the right panel.

Focusing first on the left panel, the coefficient on $C R I M E_{i t}$ is positive, as expected, for the directors and CEOs (significant at the 0.01 and 0.05 level for directors and CEOs, respectively). These results suggest that firms with more convicted/suspected directors and CEOs report more volatile earnings. ${ }^{8}$ The coefficient on $C R I M E_{i t}$ in the CFO regression is virtually zero. Regarding the control variables, as expected, the coefficients on leverage are positive, and the coefficients on firm size are negative (significant at the 0.01 level for both

\footnotetext{
${ }^{8}$ Estimating Equation (2a) without firm fixed-effects yields similar results.
} 
variables); counter to our expectations, the coefficients on the market-to-book ratios are negative (significant at the 0.01 level). Turning to the panel on the right, the coefficient on $C R I M E_{i t}$ is positive, as expected, and significant at the 0.10 level, but this coefficient is not reliably different from zero for CEOs and CFOs.

To summarize, we find evidence consistent with the argument that companies with more convicted/suspected directors and those with convicted/suspected CEOs report more volatile earnings, after controlling for financial leverage, firm size and market-to-book ratios.

We now turn to writing off acquired goodwill, a transaction directly linked to decisions made by senior executives and approved by the board of directors. We argue that companies with more convicted/suspected directors and senior executives will engage in more risky acquisitions, which in turn will lead to larger and more frequent goodwill writeoffs. Consider for example two possible acquisitions of subsidiaries. The cost of these acquisitions is the same, $\$ 1,000$. The first acquired subsidiary is expected to generate net earnings of either $\$ 50$ or $\$ 150$ with a probability of $50 \%$ each. The second acquired subsidiary is expected to generate net earnings of $-\$ 100$ or $\$ 300$ with probabilities of $50 \%$ each. Suppose negative earnings lead to a goodwill writeoff. We expect firms with more convicted/suspected directors and senior executives to choose the second acquisition due to higher propensity for risk taking, increasing the likelihood of goodwill writeoffs.

Ideally, we would examine the criminal records of board members and senior executives who actually made the decision to acquire the subsidiaries, and link this information to the goodwill writeoff. However, the timing of each, as well as board composition and the identity of senior executives at that time are not available to us. We therefore look at the criminal history of board members and senior executives for writeoffs during our sample period. Also, it is possible that changes in market conditions not within the control of the firm's directors and senior executives compel companies to write off 
acquired goodwill. Still, managerial risk taking should result in more frequent and larger goodwill writeoffs, after controlling for these exogenous factors.

To examine the association between goodwill writeoffs and directors', CEOs' and CFOs' criminal activities, we use the following models:

$$
\begin{aligned}
& \text { WO }_{i t}=\delta_{0}+\delta_{1} R T_{i t}+\delta_{2} \text { CRIME }_{i t}+\delta_{3} \text { CEOCHANGE }_{i t}+\delta_{4} R O A_{i t}+\delta_{5} \text { SIZE }_{i t}+ \\
& \delta_{6} \text { LEVERAGE }_{i t}+\delta_{7} \text { PB }_{i t}+v_{i t} \\
& \text { WRITEOFF / GOODWILL } \\
& \text { WIt }
\end{aligned}
$$

The dependent variable in Equation (4), $W O_{i t}$, is an indicator variable that obtains the value of " 1 " if firm $i$ recognized a goodwill writeoff in year $t$, and " 0 " otherwise. The dependent variable in Equation (5) is goodwill writeoff divided by the amount of goodwill before the writeoff (the proportion of goodwill written off). The main explanatory variable in Equations (4) and (5) is $C R I M E_{i t} \in\left\{B O A R D_{i t}, C E O_{i t}, C F O_{i t}\right\}$ as defined above.

We also include in both equations variables associated with goodwill writeoffs. $R E T_{i t}$ is annual stock returns. If goodwill writeoffs are recognized in a timely manner, the coefficient on this variable should be negative. CEOCHANGE $E_{i t}$ is an indicator variable that obtains the value "1" if the CEO was replaced during year $t$, and "0" otherwise. As recognition of goodwill writeoffs often occurs following a replacement of a CEO, the coefficient on this variable is expected to be positive. $R O A_{i t}$ is the return-on-assets ratio. The coefficient on this variable is expected to be negative, as more profitable firms are less likely to recognize goodwill writeoffs. SIZE $E_{i t}$ is the log of total assets. Larger companies are more likely to be scrutinized by regulators and investors, leading to more timely recognition of goodwill writeoffs. $L E V E R A G E_{i t}$ is interest-bearing debt divided by total assets. Companies with higher leverage prefer to delay goodwill writeoffs in order to avoid possible violations 
of debt covenants. Hence the coefficient on this variable is expected to be negative. Finally, $P B_{i t}$ is the market-to-book ratio. Higher share prices relative to book values suggest that goodwill writeoffs are not required; hence the coefficient on this variable is expected to be negative. We estimate Equation (4) using Logit, and Equation (5) using Tobit, as in Beatty and Weber (2006).

As Table 6 shows, the proportion of convicted/suspected directors is positively associated with the frequency and magnitude of goodwill writeoffs (coefficients on CRIME are positive at the 0.01 level). Also, goodwill writeoffs are more frequent and larger in magnitude when the CEO has been convicted/suspected of a crime (significant at the 0.05 level or better); we do not find a similar link for CFOs. A possible explanation for this last result is that while directors and CEOs enjoy the benefits of acquiring new subsidiaries, CFOs often have to deal with the negative consequences of writing off goodwill. Also, as Graham et al. (2011) argue, CEOs tend not to delegate decisions regarding acquisitions to CFOs.

The likelihood of goodwill writeoffs increases in the year of a CEO change (at the 0.05 level), consistent with prior empirical findings. Taken together, these results provide evidence suggesting that firms with more convicted/suspected directors and CEOs engage in more risky acquisitions, leading to larger and more frequent goodwill writeoffs. This result is obtained after controlling for CEOs changes.

As expected, the coefficients on annual stock returns (RET) are negative, but are not significant at the 0.10 level. A plausible explanation for this result is that writeoffs are not recognized in a timely manner, an issue addressed later. The coefficients on ROA are negative, as expected (significant at the 0.01 level in all models), suggesting that profitable companies are less likely to recognize goodwill writeoffs. Larger firms are more likely (at the 0.01 level) to recognize goodwill writeoffs due to their visibility to regulators and 
investors. Also, as expected, companies with higher market-to-book ratios $(P B)$ are less likely (at the 0.01 level) to recognize goodwill writeoffs; the coefficients on LEVERAGE are not significant at the 0.10 level.

Next, we distinguish between "good" and "bad" changes in the board of directors and senior executives. For directors, we define a "good" ("bad") change as a decrease (an increase) in the proportion of convicted/suspected board members from above (below) the sample median to below (above) the sample median. For CEOs and CFOs, a "good" ("bad") change is replacing a convicted/suspected ("clean") CEO/CFO in year $t$-1 with a "clean" (convicted/suspected) one in year $t$. Ex-ante, we expect goodwill writeoffs to follow "good" changes as well as "bad" changes because the incentives to writeoff goodwill exist in both cases. We test this hypothesis by estimating the following model using Logit:

$$
\begin{aligned}
& W O_{j t}=\delta_{0}+\delta_{1} R E T_{j t}+\delta_{2} \text { CRIME }_{j t}+\delta_{3}^{G} G O O D C H A N G E_{j t}+\delta_{3}^{B} B A D C H A N G E_{j t} \\
& +\delta_{4} R O A_{j t}+\delta_{5} S_{2 Z E_{j t}}+\delta_{6} L E V E R A G E_{j t}+\delta_{7} P B_{j t}+v_{j t}
\end{aligned}
$$

Table 7 presents results of estimating Equation (6) with and without the crime variable (CRIME). Focusing on boards of directors, the coefficients $\delta_{3}^{G}$ and $\delta_{3}^{B}$ are both positive, as expected, but only the coefficient $\delta_{3}^{G}$ is significantly larger than zero at the 0.05 level. When the crime variable is included in the model, it is positive, as expected, and significant at the 0.01 level; the coefficient on $\delta_{3}^{G}$ remains positive, and is significant at the 0.01 level. These results suggest that the likelihood of goodwill writeoff increases with the proportion of criminally convicted/suspected directors. Also, the likelihood of goodwill writeoff increases following a "good" change in the board.

Turning to the CEO regressions, when the crime variable is not included, the coefficients $\delta_{3}^{G}$ and $\delta_{3}^{B}$ are positive, as expected, and significant at the 0.10 level. However, when the crime variable is included in the model, only the coefficient $\delta_{3}^{G}$ remains positive 
and significant at the 0.10 level. The coefficient on the crime variable is also positive, as expected, and significantly larger than zero at the 0.10 level. These results suggest that goodwill writeoffs are more likely to occur after CEO replacements, regardless of whether these changes are "good" or "bad". Also, the likelihood of goodwill writeoffs increases when the CEO is convicted/suspected of a crime. As before, we do not find any association between the CFO's criminal history and goodwill writeoffs.

\subsection{Criminal Directors/Executives and Accounting Conservatism}

To examine the association between directors' and senior executives' criminal activities and accounting conservatism, we use Basu's (1997) conditional conservatism model and estimate it for firms with high proportions of convicted/suspected directors and for firms with convicted/suspected CEOs and CFOs. For comparison, we also estimate the model for firms without convicted/suspected directors, CEOs or CFOs. Finding that firms with convicted/suspected directors and senior executives exhibit a lower degree of accounting conservatism would support the argument that more frequent and larger goodwill writeoffs made by firms with convicted directors and CEOs should not be attributed to more conservative accounting, but rather to more risky acquisitions.

While Basu's (1997) model has been widely used as a measure of conditional conservatism, it has also been criticized as yielding biased results due to variable scaling, truncation, the distribution of price-deflated earnings, correlated omitted variables, and the endogeneity of stock returns (Dietrich et al., 2007; Patatoukas and Thomas, 2011; Givoly et al., 2007). However, Ball et al. (2011) argue that using firm fixed-effects reduces bias in the model's estimated coefficients. We therefore use the following model: 


$$
\begin{aligned}
E P_{j t} & =\phi_{0}+\sum_{s=1999}^{2007} \phi_{s} Y E A R_{s}+\sum_{i=1}^{I} \phi_{i} \text { IIRM }_{i}+\phi_{1} R E T_{j t}+\phi_{2} D_{R E T_{j t}}+\phi_{3} R E T_{j t} \times D R E T_{j t} \\
& +\phi_{8} S I Z E_{j t}+\phi_{9} L E V E R A G E_{j t}+\phi_{10} P B_{j t}+v_{j t}
\end{aligned}
$$

The dependent variable $\left(E P_{i t}\right)$ is annual earnings per share divided by last year's stock price. Independent variables include $R E T_{i t}$ - annual stock return; and $D R E T_{i t}$ - an indicator variable that obtains the value " 1 " if $R E T_{i t}$ is negative, and " 0 " otherwise. We also use SIZE (log of total assets), LEVERAGE (interest-bearing debt divided by total assets), and $P B$ (market-to-book ratio) as control variables. Based on prior studies, we expect larger firms to have higher earnings-to-price ratios and firms with higher leverage and higher market-tobook ratios to have lower earnings-to-price ratios.

Table 8, Panel A, presents results for companies with more than $50 \%$ convicted/ suspected directors, convicted/suspected CEOs, and convicted/suspected CFOs, respectively. Here, the coefficients on $R E T_{i t} \times D R E T_{i t}$ are not significantly different from zero at the 0.10 level, suggesting that bad news is not recognized in a more timely manner than good news. That is, accounting in these companies is not conservative according to Basu's (1997) model. Panel B presents results for companies with $50 \%$ or less convicted/suspected directors, and companies with "clean" CEOs and CFOs. As can be seen, the coefficients on $R E T_{j t} \times D R E T_{j t}$ are positive, as expected, and significant at the 0.01 level in these three regressions. This result is consistent with prior findings, namely bad news is generally recognized in earnings faster than good news.

We also estimate Equation (7) using the entire sample, allowing the coefficients to vary by whether the firms have convicted/suspected directors/CEOs/CFOs. This way we test whether the variables in Equation (7) are different across the two subsamples. The results (not tabulated) show that the interaction variable $R E T_{j t} \times D R E T_{j t} \times D_{j t}$, where $D_{j t}$ obtains the value " 1 " for the firms with convicted/suspected directors or senior executives, and " 0 " 
otherwise, is significantly negative for directors (at the 0.01 level) and for CEOs (at the 0.05 level), but not for CFOs. Taken together, these results support the argument that companies with more convicted/suspected directors and senior executives do not report as conservatively as firms without such directors and senior executives

\section{Summary and Conclusions}

Using a database on crime convictions, we find that non-trivial proportions of board members, CEOs and CFOs in Swedish listed companies have been convicted or suspected of crimes. Based on existing research, we argue that directors and senior executives who have been convicted or suspected of serious crimes exhibit a higher propensity for risk taking. Hence, we examine whether firms led by individuals who have been convicted/suspected of crimes engage more in risky activities. In particular, we examine whether such firms report more volatile earnings, engage in more risky acquisitions of subsidiaries, and report less conservatively.

Our main contribution is introducing personal criminal convictions as a measure of excessive managerial risk taking and linking it to corporate decisions and subsequent accounting outcomes. We also contribute to the literature by looking at the joint effect of directors and CEOs on corporate risk-taking. Finally, we expand on the effect of CEO personal attributes on the outcome of acquisitions by looking at goodwill writeoffs.

We find that companies with more convicted/suspected directors and companies led by CEOs who have been convicted/suspected of a crime report more volatile earnings; we do not find such a link for CFOs. In addition, we find that companies with more convicted/suspected directors and companies led by convicted/suspected CEOs report more frequent and larger goodwill writeoffs. Also, goodwill writeoffs are more likely to occur when the proportion of convicted/suspected directors declines and when a 
convicted/suspected CEO is replaced by a CEO without criminal convictions, suggesting that the incoming "clean" directors and CEOs write off existing goodwill from past high-risk acquisitions made by former directors and CEOs. Taken together, these results are consistent with the argument that convicted/suspected directors and CEOs take additional risks, leading to more unsuccessful acquisitions, which in turn leads to more frequent and larger goodwill writeoffs. We do not, however, find a significant link between goodwill writeoffs and CFOs' criminal activities, consistent with the argument that CFOs are less involved in acquisitionrelated decisions.

As recognition of goodwill writeoffs may indicate conservative accounting, if these writeoffs are recognized in a timely manner, we examine the timeliness of recognizing bad news in earnings using Basu's (1997) model. We find that earnings of firms with more convicted/suspected directors and firms led by convicted/suspected CEOs are not conservative according to Basu's (1997) model.

The policy implication of our study is that criminal convictions should be disclosed to the firm's stakeholders, as criminal history is associated with more risky corporate decisions and with the quality of financial reporting.

Our results may also have direct implications for future research on corporate governance and regulatory intervention. A natural corollary to our study is to examine the association between criminal activities of senior executives and corporate decisions in US companies, where the overall crime rates are higher than in Sweden. It would also be interesting to examine whether companies accused of accounting fraud, companies sanctioned by the SEC and companies that restated their financial statements had appointed relatively more convicted directors and senior executives. 


\section{References}

Adams, R.B., and D. Ferreira (2009). Women in the boardroom and their impact on governance and performance, Journal of Financial Economics 94: 291-309.

Aktas, N., E. de Bodt, H. Bollaert, and R. Roll (2010). CEO narcissism and takeover process, Working Paper (July), UCLA.

Amir, E., J.P. Kallunki, and H. Nilsson (2012). The association between individual audit partners' risk preferences and the composition of their client portfolios, Review of Accounting Studies (Forthcoming).

Ball, R., S.P. Kothari, and V. Nikolaev (2011). On estimating conditional conservatism, Working Paper (February), University of Chicago.

Bamber, L., J. Jiang, and I. Wang (2010), What's my style? The influence of top managers on voluntary corporate financial disclosure. The Accounting Review 85 (4): 1131-1162.

Basu, S. (1997). The conservatism principle and the asymmetric timeliness of earnings, Journal of Accounting and Economics 24 (1): 3-37.

Beatty, A., and J. Weber (2006). Accounting discretion in fair value estimates: and examination of SFAS 142 goodwill impairments, Journal of Accounting Research 44 (2): 257-288.

Becker, G.S. (1968). Crime and punishment: An economic approach, Journal of Political Economy 76 (2): 169-217.

Blickle, G., A. Schlegel, P. Fassbender, and U. Klein (2006). Some personality correlates of business white-collar crime, Applied Psychology: An International Review 55: 220-233.

Cain, M.D., and McKeon, S.B. (2012). CEO personal risk-taking and corporate policies, Working Paper (May), University of Notre Dame.

Daly, K. (1989). Gender and varieties of white-collar crime, Criminology 27 (4): 769-794.

Dietrich, D., K. Muller, and E. Riedl (2007). Asymmetric timeliness tests of accounting conservatism, Review of Accounting Studies 12: 95-124.

Dolmén, L. (2001). The criminality in different countries, Brå-report, the Swedish National Council for Crime Prevention 18: 1-52.

Dyreng, S., M. Hanlon, and E. Maydew (2010). The effects of executives on corporate tax avoidance, The Accounting Review 85 (4): 1163-1189.

Ehrlich, I. (1973). Participation in illegitimate activities: A theoretical and empirical investigation, Journal of Political Economy 81 (3): 521-65. 
Eide, E., P.H. Rubin, and J.M. Shepherd (2006). Economics of crime, Foundations and Trends in Microeconomics 2 (3), Now Publishers, Hanover, MA, USA.

Fama, E.F., and K. R. French (1992). The cross-section of expected stock returns, Journal of Finance 47 (2): 427-465.

Garoupa, N. (2003). Behavioral economic analysis of crime: A critical review, European Journal of Law and Economics 15: 5-15.

Givoly, D., C. Hayn, and A. Natarajan (2007). Measuring reporting conservatism, The Accounting Review 82: 65-106.

Graham, J.R., Campbell, R.H., and M. Puri (2010). Capital allocation and delegation of decision making authority within firms. NBER Working paper.

Grinblatt, M., and M. Keloharju (2009). Sensation seeking, overconfidence and trading activity, Journal of Finance 64: 549-578.

Hambrick, D.C., and P.A. Mason (1984). Upper Echelons: The organization as a reflection of its top managers, The Academy of Management Review 9 (2): 193-206.

Hvide, H.K. (2002). Tournament rewards and risk taking. Journal of Labor Economics 20 (4): 877-898.

Iversen, H., and T. Rundmo (2002), Personality, risky driving and accident involment among Norwegian drivers, Personality and Individual Differences 33: 1251-1263.

Jones, R., B. Lasky, H. Russell-Gale, and K. le Fevre (2004). Leadership and the development of dominant and counter cultures: A narcissistic perspective, Leadership and Organization Development Journal 25 (2): 216-233.

Korsell, L. (2001). Three decades of researching and combating economic crime - the Swedish case, in S.A. Lindgren (ed.), White-Collar Crime Research. Old Views and Future Potentials, Stockholm, The National Council for Crime Prevention, pp. 91-106.

La Porta, R., F. Lopez-de-Silanes, A. Shleifer, and R.W. Vishny (1998). Law and finance, Journal of Political Economy 106 (6): 1113-1155.

Larcker, D., G. Richardson, and I. Tuna (2007). Corporate governance, accounting outcomes, and organizational performance, The Accounting Review 82 (4): 963-1008.

Leuz C., D. Nanda, and P. Wysocki, (2003). Earnings management and investor protection: An international comparison, Journal of Financial Economics 69: 505-527.

Libby, R., and K. Rennekamp (2012). Self-serving attribution bias, overconfidence, and the issuance of management forecasts, Journal of Accounting Research 50 (1): 197-231.

Malmendier, U., and J. Tate (2008). Who makes acquisitions? CEO overconfidence and the market's reaction, Journal of Financial Economics 89 (1): 20-43. 
Palmer, E.J., and C.R. Hollin (2004). Predicting reconviction using the Psychological Inventory of Criminal Thinking Styles with English prisoners, Legal and Criminological Psychology 9: 57-68.

Patatoukas, P.N., and J.K. Thomas (2011). More evidence of bias in the differential timeliness measure of conditional conservatism, The Accounting Review 86 (5): 1765-1793.

Pech, R. J., and B.W. Slade (2007). Organizational sociopaths: Rarely challenged, often promoted. Why? Society and Business Review 2 (3): 254-269.

Petersen, M.A. (2009). Estimating standard errors in finance panel data sets: Comparing approaches, Review of Financial Studies 22: 435-480.

Qiang, X (2007). The effects of contracting, litigation, regulation, and tax costs on conditional and unconditional conservatism: Cross-sectional evidence at the firm level. The Accounting Review 82 (3): 759-796.

Sandroni, A., and F. Squintani (2004). A survey on overconfidence, insurance and selfassessment training programs, Working Paper, Kellogg School of Management.

Stoll, M.A., and S.D. Bushway (2008). The effect of criminal background checks on hiring ex-offenders, Criminology \& Public Policy 7 (3): 371-404.

Strömholm, S. (1991). An Introduction to Swedish Law, $2^{\text {nd }}$ ed., Stockholm, Norstedts Förlag.

Svensson, R. (2000). Strategic Crimes - What type of crimes predicts a future criminal career, Brå-report, the Swedish National Council for Crime Prevention 3: 1-53.

Unger, S. (2006). Special features of Swedish corporate governance, The Swedish Corporate Governance Board: 1-19.

Walters, G.D. (2009). The psychological inventory of criminal thinking styles and psychopathy checklist: Screening version as incrementally valid predictors of recidivism, Law and Human Behavior 33: 497-505.

Zahra, R., L. Priem, and A.M.A. Rasheer (2005). The antecedents and consequences of top management fraud, Journal of Management 31: 803-828. 


\section{Table 1 \\ Sample Selection}

\begin{tabular}{lcc}
\hline & $\begin{array}{c}\text { Number of } \\
\text { Companies }\end{array}$ & $\begin{array}{c}\text { Firm-year } \\
\text { Observations }\end{array}$ \\
\hline All listed Swedish companies & 650 & 3,560 \\
Companies after deleting financial institutions & 605 & 3,265 \\
Companies with required current and lagged data & 348 & 1,902 \\
Companies after removing outliers & 334 & 1,754 \\
\hline
\end{tabular}

Note: The table presents information on the sample selection process in terms of firms and the corresponding number of observations. The sample includes industrial companies with complete current and lagged data, listed on the Swedish stock markets for the period 19992007 and monitored by the Swedish Financial Supervisory Authority. We removed observations for which the financial variables were above (below) the $99^{\text {th }}\left(1^{\text {st }}\right)$ percentile of the distribution. This process resulted in removing 14 firms (148 observations). 
Table 2

Directors, CEOs and CFOs with Criminal Convictions

Panel A: Frequency of criminal convictions

\begin{tabular}{lccccc}
\hline & \multicolumn{2}{c}{ Convicted and/or Suspected } & $\begin{array}{c}\text { Not Convicted } \\
\text { or Suspected }\end{array}$ & Total \\
\hline \multirow{3}{*}{ Board of Directors } & Convicted & Suspected & All & & \\
\cline { 2 - 6 } & 727 & 128 & 855 & 2,518 & 3,373 \\
CEOs & $(21.6 \%)$ & $(3.8 \%)$ & $(25.3 \%)$ & $(74.7 \%)$ & $(100 \%)$ \\
& 182 & 25 & 207 & 373 & 580 \\
CFOs & $(31.3 \%)$ & $(4.3 \%)$ & $(35.7 \%)$ & $(64.3 \%)$ & $(100 \%)$ \\
& 78 & 11 & 89 & 275 & 364 \\
10\% Block-Holders & $(21.4 \%)$ & $(3.0 \%)$ & $(24.5 \%)$ & $(75.5 \%)$ & $(100 \%)$ \\
& 118 & 31 & 149 & 188 & 337 \\
& $(35.0 \%)$ & $(9.2 \%)$ & $(44.2 \%)$ & $(55.8 \%)$ & $(100 \%)$ \\
\hline
\end{tabular}

Panel B: Descriptive statistics of the key crime variables

\begin{tabular}{|c|c|c|c|c|c|}
\hline & Mean & Median & Std. & Min & Max \\
\hline \multicolumn{6}{|c|}{ Total sample (1,762 observations) } \\
\hline BOARD & 0.30 & 0.29 & 0.19 & 0.00 & 1.00 \\
\hline CEO & 0.34 & 0.00 & 0.48 & 0.00 & 1.00 \\
\hline $\mathrm{CFO}$ & 0.17 & 0.00 & 0.37 & 0.00 & 1.00 \\
\hline
\end{tabular}

Panel C: Crime variables by Industry (Fama and French 5-Industry classification)

\begin{tabular}{clcccc}
\hline Industry & \multicolumn{1}{c}{ Type } & $\begin{array}{c}\text { Firm-year } \\
\text { observations }\end{array}$ & BOARD & CEO & CFO \\
\hline FF 1 & Consumer & 308 & 0.27 & 0.26 & 0.25 \\
FF 2 & Manufacturing & 569 & 0.28 & 0.32 & 0.15 \\
FF 3 & Hi-Tech & 59 & 0.36 & 0.56 & 0.14 \\
FF 4 & Health and Drugs & 20 & 0.30 & 0.85 & 0.35 \\
FF 5 & Other & 798 & 0.32 & 0.37 & 0.18 \\
\hline
\end{tabular}

Panel D: Pair-wise Pearson (above diagonal) and Spearman (below diagonal) correlations between crime variables and selected variables

\begin{tabular}{|c|c|c|c|c|c|c|c|}
\hline & BOARD & CEO & CFO & $\begin{array}{c}\text { BOARD } \\
\text { SIZE }\end{array}$ & SIZE & CEODUAL & $\begin{array}{c}\text { BLOCK } \\
\text { HOLD }\end{array}$ \\
\hline BOARD & & 0.22 & -0.03 & -0.19 & -0.16 & 0.02 & 0.18 \\
\hline CEO & 0.21 & & 0.01 & -0.05 & 0.01 & 0.00 & 0.00 \\
\hline CFO & -0.02 & 0.01 & & 0.08 & 0.15 & -0.07 & 0.01 \\
\hline BOARDSIZE & -0.18 & -0.06 & 0.08 & & 0.59 & 0.10 & -0.18 \\
\hline SIZE & -0.15 & 0.00 & 0.15 & 0.60 & & 0.10 & -0.28 \\
\hline CEODUAL & 0.01 & 0.00 & -0.07 & 0.10 & 0.11 & & 0.02 \\
\hline BLOCKHOLD & 0.18 & 0.00 & 0.01 & -0.19 & -0.26 & 0.02 & \\
\hline
\end{tabular}


Notes:

1. Panel A presents the number of individuals and proportions of convicted/suspected directors, CEOs, CFOs and 10\% block-holders in Swedish listed companies. Panel B presents the distribution of the three crime variables: BOARD, $C E O$, and $C F O$. Panel $\mathrm{C}$ presents mean crime variables by industry. Panel $\mathrm{D}$ presents selected correlations.

2. Variables are defined as follows: $B O A R D$ is the proportion of board members convicted or suspected of crimes; $C E O(C F O)$ is an indicator variable that obtains the value of "1", if the CEO (CFO) has been convicted or suspected of a crime, and " 0 " otherwise; $B L O C K H O L D$ is an indicator variable that obtains the value of " 1 " if there is at least one controlling shareholder (owning $10 \%$ or more of the firm's equity) in the firm, and " 0 " otherwise; BOARDSIZE is the logarithm of the total number of board members; SIZE is the logarithm of total assets; CEODUAL is an indicator variable that obtains the value of " 1 " if the CEO of the firm is also a member of the board, and " 0 " otherwise.

3. Industry classification is based on the Fama-French 5-industry classification (http://mba.tuck.dartmouth.edu/pages/faculty/ken.french/Data_Library/changes_ind.html) 
Table 3

Characteristics of Sample Firms - Univariate Analysis

\begin{tabular}{|c|c|c|c|c|c|c|c|c|c|}
\hline & \multicolumn{3}{|c|}{ Directors } & \multicolumn{3}{|c|}{ Chief Executive Officers (CEO) } & \multicolumn{3}{|c|}{ Chief Financial Officers (CFO) } \\
\hline & $\begin{array}{c}50 \% \text { or } \\
\text { more } \\
\text { Convicted } \\
(\mathrm{N}=\mathbf{3 3 0}) \\
\end{array}$ & $\begin{array}{c}\text { Less than } \\
50 \% \\
\text { Convicted } \\
(\mathrm{N}=\mathbf{1 , 4 2 4}) \\
\end{array}$ & Diff & $\begin{array}{c}\text { CEO } \\
\text { Convicted } \\
(\mathrm{N}=602)\end{array}$ & $\begin{array}{l}\text { CEO not } \\
\text { Convicted } \\
(\mathrm{N}=\mathbf{1 , 1 5 2})\end{array}$ & Diff & $\begin{array}{c}\text { CFO } \\
\text { Convicted } \\
(\mathrm{N}=\mathbf{2 9 0})\end{array}$ & $\begin{array}{c}\text { CFO not } \\
\text { Convicted } \\
(\mathrm{N}=\mathbf{1 , 4 6 4})\end{array}$ & Diff \\
\hline & $\begin{array}{c}\text { Mean } \\
\text { Median }\end{array}$ & $\begin{array}{c}\text { Mean } \\
\text { Median }\end{array}$ & $\begin{array}{c}\text { t-test } \\
\text { Wilcoxon }\end{array}$ & $\begin{array}{c}\text { Mean } \\
\text { Median }\end{array}$ & $\begin{array}{c}\text { Mean } \\
\text { Median }\end{array}$ & $\begin{array}{c}\text { t-test } \\
\text { Wilcoxon }\end{array}$ & $\begin{array}{c}\text { Mean } \\
\text { Median }\end{array}$ & $\begin{array}{c}\text { Mean } \\
\text { Median }\end{array}$ & $\begin{array}{c}\text { t-test } \\
\text { Wilcoxon }\end{array}$ \\
\hline ABSEC & $\begin{array}{l}0.15 \\
0.06\end{array}$ & $\begin{array}{l}0.11 \\
0.04\end{array}$ & $\begin{array}{l}3.64++ \\
4.74++\end{array}$ & $\begin{array}{l}0.13 \\
0.05\end{array}$ & $\begin{array}{l}0.10 \\
0.04\end{array}$ & $\begin{array}{l}2.93++ \\
3.08++\end{array}$ & $\begin{array}{l}0.10 \\
0.04\end{array}$ & $\begin{array}{l}0.12 \\
0.04\end{array}$ & $\begin{array}{r}-0.92 \\
1.47\end{array}$ \\
\hline EVOL & $\begin{array}{l}0.31 \\
0.12\end{array}$ & $\begin{array}{l}0.12 \\
0.09\end{array}$ & $\begin{array}{l}3.93++ \\
7.08++\end{array}$ & $\begin{array}{l}0.21 \\
0.10\end{array}$ & $\begin{array}{l}0.13 \\
0.09\end{array}$ & $\begin{array}{l}2.20+ \\
2.24+\end{array}$ & $\begin{array}{l}0.12 \\
0.07\end{array}$ & $\begin{array}{l}0.16 \\
0.10\end{array}$ & $\begin{array}{l}-0.89 \\
\mathbf{3 . 4 6 + +}\end{array}$ \\
\hline$W O$ & $\begin{array}{l}0.10 \\
0.00\end{array}$ & $\begin{array}{l}0.09 \\
0.00\end{array}$ & $\begin{array}{l}0.53 \\
0.52\end{array}$ & $\begin{array}{l}0.11 \\
0.00\end{array}$ & $\begin{array}{l}0.08 \\
0.00\end{array}$ & $\begin{array}{l}2.14+ \\
2.13+\end{array}$ & $\begin{array}{l}0.10 \\
0.00\end{array}$ & $\begin{array}{l}0.09 \\
0.00\end{array}$ & $\begin{array}{l}0.73 \\
0.72\end{array}$ \\
\hline WO/GOODWILL & $\begin{array}{l}0.02 \\
0.00\end{array}$ & $\begin{array}{l}0.01 \\
0.00\end{array}$ & $\begin{array}{l}0.72 \\
0.92\end{array}$ & $\begin{array}{l}0.02 \\
0.00\end{array}$ & $\begin{array}{l}0.01 \\
0.00\end{array}$ & $\begin{array}{l}2.90++ \\
3.13++\end{array}$ & $\begin{array}{l}0.01 \\
0.00\end{array}$ & $\begin{array}{l}0.01 \\
0.00\end{array}$ & $\begin{array}{l}0.17 \\
0.99\end{array}$ \\
\hline $\boldsymbol{E P}$ & $\begin{array}{r}-0.06 \\
0.01\end{array}$ & $\begin{array}{r}-0.00 \\
0.04\end{array}$ & $\begin{array}{c}-4.60++ \\
4.83++\end{array}$ & $\begin{array}{r}-0.03 \\
0.03\end{array}$ & $\begin{array}{r}-0.01 \\
0.03\end{array}$ & $\begin{array}{c}\mathbf{- 1 . 9 3 *} \\
1.15\end{array}$ & $\begin{array}{l}0.00 \\
0.06\end{array}$ & $\begin{array}{r}-0.02 \\
0.03\end{array}$ & $\begin{array}{l}1.59 \\
\mathbf{3 . 4 6 + +}\end{array}$ \\
\hline OPACC & $\begin{array}{l}-0.01 \\
-0.00\end{array}$ & $\begin{array}{l}0.01 \\
0.01\end{array}$ & $\begin{array}{c}-2.87++ \\
2.75++\end{array}$ & $\begin{array}{l}0.00 \\
0.00\end{array}$ & $\begin{array}{l}0.01 \\
0.01\end{array}$ & $\begin{array}{l}1.54 \\
0.88\end{array}$ & $\begin{array}{l}0.01 \\
0.00\end{array}$ & $\begin{array}{l}0.00 \\
0.01\end{array}$ & $\begin{array}{l}0.25 \\
0.59\end{array}$ \\
\hline SIZE & $\begin{array}{l}5.88 \\
5.69\end{array}$ & $\begin{array}{l}7.02 \\
6.74\end{array}$ & $\begin{array}{c}\mathbf{- 8 . 9 8 + +} \\
8.74++\end{array}$ & $\begin{array}{l}6.82 \\
6.69\end{array}$ & $\begin{array}{l}6.79 \\
6.55\end{array}$ & $\begin{array}{l}0.26 \\
0.15\end{array}$ & $\begin{array}{l}7.52 \\
7.26\end{array}$ & $\begin{array}{l}6.66 \\
6.48\end{array}$ & $\begin{array}{l}6.34++ \\
5.99++\end{array}$ \\
\hline LEVERAGE & $\begin{array}{l}0.17 \\
0.15\end{array}$ & $\begin{array}{l}0.17 \\
0.15\end{array}$ & $\begin{array}{r}-0.66 \\
1.40\end{array}$ & $\begin{array}{l}0.17 \\
0.13\end{array}$ & $\begin{array}{l}0.17 \\
0.14\end{array}$ & $\begin{array}{l}0.20 \\
0.01\end{array}$ & $\begin{array}{l}0.19 \\
0.17\end{array}$ & $\begin{array}{l}0.16 \\
0.13\end{array}$ & $\begin{array}{l}2.20+ \\
2.72++\end{array}$ \\
\hline$P B$ & $\begin{array}{l}3.06 \\
2.14\end{array}$ & $\begin{array}{l}2.98 \\
2.19\end{array}$ & $\begin{array}{l}0.52 \\
0.49 \\
\end{array}$ & $\begin{array}{l}3.04 \\
2.16 \\
\end{array}$ & $\begin{array}{l}2.97 \\
2.19 \\
\end{array}$ & $\begin{array}{l}0.55 \\
0.45\end{array}$ & $\begin{array}{l}2.94 \\
2.19 \\
\end{array}$ & $\begin{array}{l}3.00 \\
2.17\end{array}$ & $\begin{array}{r}-0.39 \\
0.83 \\
\end{array}$ \\
\hline
\end{tabular}


Notes:

1. The table presents descriptive statistics for the sample of industrial companies with required current and lagged data, listed on the Swedish stock markets for the period 1999-2007 and monitored by the Swedish Financial Supervisory Authority. We present means and medians for companies for which more (less) than $50 \%$ of the directors have been convicted/suspected of a crime; companies for which the CEO has been convicted/suspected (not convicted/suspected) of a crime; and companies for which the CFO has been convicted/suspected (not convicted/suspected) of a crime. We also present $t$-statistics for differences in means (medians) between subsamples.

2. Variables are defined as follows:

a) $A B S E C$ - The absolute value of annual earnings changes divided by market value of equity at the beginning of the year

b) $E V O L$ - Standard deviation of earnings scaled by total assets

c) $W O$ - A dummy variable equal to " 1 " if the firm recognizes a goodwill writeoff, and "0" otherwise

d) WO/GOODWILL - Goodwill writeoffs divided by the amount of goodwill before the writeoff (the proportion of goodwill written off)

e) $E P$ - Earnings per share divided by the beginning of year share price

f) $O P A C C$ - Operating accruals measured as:

OPACC $_{i t}=\Delta$ Inventory $_{i t}+\Delta \operatorname{Re}$ cievables $_{i t}+\Delta$ Other current assets $_{i t}-\Delta$ Payables $_{i t}-\Delta$ Other current liabilities $_{i t}-$ Depreciation $_{i t}$

g) SIZE - Logarithm of total assets

h) LEVERAGE - Total interest-bearing debt divided by total assets

i) $P B$ - Market value of equity divided by book value of equity).

3.,,$+++ *$ Significant at the $0.01,0.05$, and 0.10 levels, respectively. 


\section{Table 4}

\section{Determinants of Proportions of Convicted Directors and Senior Executives}

\begin{tabular}{lcccc}
\hline Variable & $\begin{array}{c}\text { Exp. } \\
\text { Sign }\end{array}$ & $\begin{array}{c}\text { Board } \\
\text { Members }\end{array}$ & CEO & CFO \\
\hline BOARD & + & -- & $\mathbf{2 . 3 1}$ & -0.21 \\
& & & $(\mathbf{6 2 . 0 3})++$ & $(0.28)$ \\
CEO & + & $\mathbf{0 . 0 3}$ & -- & 0.11 \\
& & $(\mathbf{1 . 9 1})^{*}$ & & $(0.59)$ \\
CFO & + & 0.00 & 0.15 & -- \\
& & $(0.05)$ & $(1.05)$ & \\
MALE & + & $\mathbf{0 . 1 7}$ & 0.53 & -0.11 \\
& & $(\mathbf{4 . 1 3})++$ & $(1.38)$ & $(0.04)$ \\
BUSY & $?$ & 0.02 & $\mathbf{- 0 . 6 3}$ & $\mathbf{1 . 7 0}$ \\
& & $(0.48)$ & $(\mathbf{2 . 7 9})^{*}$ & $(\mathbf{1 4 . 4 7 ) + +}$ \\
CEODUAL & + & $\mathbf{0 . 0 2}$ & 0.05 & -0.55 \\
& & $(\mathbf{1 . 8 5})^{*}$ & $(0.19)$ & $(14.10)++$ \\
BOARDSIZE & + & -0.01 & -1.03 & 0.02 \\
& & $(-0.43)$ & $(15.11)++$ & $(0.00)$ \\
BLOCKHOLD & - & 0.01 & -0.12 & 0.40 \\
& & $(0.75)$ & $(1.18)$ & $(7.43)++$ \\
EMPLOYEE & - & -0.04 & 0.34 & 0.05 \\
& & $(-0.04)$ & $(0.49)$ & $(0.00)$ \\
AGE & + & -0.00 & -0.02 & $\mathbf{0 . 0 4}$ \\
& & $(-1.34)$ & $(1.91)$ & $(\mathbf{8 . 7 8})++$ \\
LEVERAGE & $?$ & 0.01 & 0.05 & -0.02 \\
& & $(0.27)$ & $(0.02)$ & $(0.00)$ \\
SIZE & - & $-\mathbf{0 . 0 1}$ & 0.19 & 0.20 \\
& & $(-1.82)^{*}$ & $(19.61)++$ & $(13.34)++$ \\
PB & $?$ & -0.00 & 0.02 & 0.02 \\
& & $(-1.06)$ & $(0.94)$ & $(0.62)$ \\
\hline Adjusted R ${ }^{2}$ & & 0.17 & 0.09 & 0.06 \\
Observations & & 1,762 & 1,762 & 1,762 \\
\hline & & & & \\
& & & &
\end{tabular}

*Notes:

1. The table provides results for estimating Equation (1). The dependent variable, CRIME, measures the magnitude of crime convictions for directors, CEOs and CFOs. BOARD - the proportion of board members convicted or suspected of crimes; (2) $C E O$ - an indicator variable taking the value of " 1 " if the $C E O$ has been convicted or suspected of crimes, and " 0 " otherwise; (3) $C F O$ - an indicator variable taking the value of " 1 " if the $C F O$ has been convicted or suspected of crimes, and " 0 " otherwise. 
2. Independent variables include the two crime variables that are not used as a dependent variable in the model. For example, when the dependent variable is BOARD, the model includes $\mathrm{CEO}$ and $\mathrm{CFO}$ on the right-hand side of the equation. In addition, we use the following dependent variables:

- $M A L E_{i t}$ - The proportion of male board members for firm $i$ at year-end $t$

- $B U S Y_{i t}$ - The proportion of board members with three or more board memberships in the listed Swedish firms for firm $i$ at year-end $t$

- CEODUAL $L_{i t}$ - An indicator variable that obtains the value of " 1 " if the CEO of firm $i$ at year-end $t$ is also a member of the board, and " 0 " otherwise

- BOARDSIZE $E_{i t}$ - The logarithm of the total number of board members for firm $i$ at yearend $t$

- BLOCKHOLD $D_{i t}$ - An indicator variable that obtains the value of " 1 " if there is at least one controlling shareholder (owning 10\% or more of the firm's equity) in the firm $i$ at year-end $t$, and " 0 " otherwise

- EMPLOYEE $E_{i t}$ - The proportion of employee representatives on the board of firm $i$ at year-end $t$

- $A G E_{i t}$ - The average age of the board members of firm $i$ at year-end $t$

- LEVERAGE $E_{i t}$ - Interest-bearing debt divided by total assets

- $S I Z E_{i t}-$ Logarithm of total assets

- $P B_{i t}$ - Market value of equity divided by book value of equity.

3. The model for board members is:

$$
\begin{aligned}
& \text { BOARD }_{i t}=\alpha_{0}+\sum_{s=1999}^{2007} \alpha_{s} \text { YEAR }_{s}+\sum_{i=1}^{I} \alpha_{i} \text { FIRM }_{i}+\beta_{1} C E O_{i t}+\beta_{2} C F O_{i t}+\beta_{3} M_{A L E}+\beta_{4} \text { BUSY }_{i t}+ \\
& \beta_{5} \text { CEODUAL }_{i t}+\beta_{6} \text { BOARDSIZE }_{i t}+\beta_{7} \text { BLOCKHOLD }_{i t}+\beta_{8} \text { EMPLOYEE }_{i t}+\beta_{9} A G E_{i t} \\
& +\beta_{10} L E V E R A G E_{i t}+\beta_{11} S I Z E_{i t}+\beta_{12} P B_{i t}+\varepsilon_{i t}
\end{aligned}
$$

4. For the proportion of convicted/suspected board members as the dependent variable, we estimate Equation (1) by using OLS. For the dummy variables of convicted/suspected CEOs and CFOs, we estimate Equation (1) by using logistic regressions.

5. Pooled regressions are estimated using pooled data with firm and year fixed-effects. All $t$ values in the pooled regression are based on heteroskedasticity-adjusted standard errors. We also take into account the firm-level clustering in standard errors as in Petersen (2009). Specifically, we allow both a firm and time effect to be present in the panel data and address the time effect parametrically by including yearly dummies and then estimate standard errors clustered on the firm dimension.

6.,$+++{ }^{*}-$ Significant at the $0.01,0.05$, and 0.10 levels, respectively. 


\section{Table 5}

The Association between Criminal Convictions and Earnings Volatility

\begin{tabular}{|c|c|c|c|c|c|c|c|c|}
\hline & Sign & Directors & CEOs & CFOs & Sign & Directors & CEOs & CFOs \\
\hline & & \multicolumn{3}{|c|}{ Dep. Var. $=$ ABSEC } & & \multicolumn{3}{|c|}{ Dep. Var. = EVOL } \\
\hline CRIME & + & $\begin{array}{c}0.23 \\
(3.25)++\end{array}$ & $\begin{array}{c}0.06 \\
(2.07)+\end{array}$ & $\begin{array}{l}0.006 \\
(0.02)\end{array}$ & + & $\begin{array}{c}38.72 \\
(1.77) *\end{array}$ & $\begin{array}{c}9.18 \\
(0.95)\end{array}$ & $\begin{array}{c}-6.47 \\
(-0.39)\end{array}$ \\
\hline LEVERAGE & + & $\begin{array}{c}0.10 \\
(3.39)++\end{array}$ & $\begin{array}{c}0.11 \\
(3.51)++\end{array}$ & $\begin{array}{c}0.11 \\
(3.52)++\end{array}$ & + & $\begin{array}{c}0.17 \\
(3.05)++\end{array}$ & $\begin{array}{c}0.18 \\
(3.13)++\end{array}$ & $\begin{array}{c}0.18 \\
(3.10)++\end{array}$ \\
\hline SIZE & - & $\begin{array}{c}-0.33 \\
(-10.28)++\end{array}$ & $\begin{array}{c}-0.30 \\
(-10.99)++\end{array}$ & $\begin{array}{c}-0.34 \\
(-10.59)++\end{array}$ & - & $\begin{array}{c}-0.32 \\
(-5.81)++\end{array}$ & $\begin{array}{c}-0.33 \\
(-6.08)++\end{array}$ & $\begin{array}{c}-0.33 \\
(-6.00)++\end{array}$ \\
\hline$P B$ & + & $\begin{array}{c}-0.29 \\
(-9.63)++\end{array}$ & $\begin{array}{c}-0.29 \\
(-9.72)++\end{array}$ & $\begin{array}{c}-0.29 \\
(-9.72)++\end{array}$ & + & $\begin{array}{c}-0.33 \\
(-6.82)++\end{array}$ & $\begin{array}{c}-0.32 \\
(-6.55)++\end{array}$ & $\begin{array}{c}-0.32 \\
(-6.62)++\end{array}$ \\
\hline $\begin{array}{l}\text { Adj-R } R^{2} \\
\text { Observations }\end{array}$ & & $\begin{array}{c}0.10 \\
1,754\end{array}$ & $\begin{array}{c}0.10 \\
1,754\end{array}$ & $\begin{array}{c}0.10 \\
1,754\end{array}$ & & $\begin{array}{l}0.23 \\
334\end{array}$ & $\begin{array}{l}0.24 \\
334\end{array}$ & $\begin{array}{l}0.23 \\
334\end{array}$ \\
\hline
\end{tabular}

Notes:

1. The table presents results of estimating the following models using rank regressions:

$$
\begin{aligned}
& \text { ABSEC }_{i t}=\alpha_{0}+\sum_{s=1999}^{2007} \alpha_{s} \text { YEAR }_{s}+\sum_{i=1}^{I} \alpha_{i} \text { FIRM }_{i}+\gamma_{1} \text { CRIME }_{i t}+\gamma_{2} \text { LEVERAGE }_{i t}+\gamma_{3} \text { SIZE }_{i t}+\gamma_{4} P B_{i t}+\varepsilon_{i t} \\
& \text { EVOL }_{i}=\alpha_{0}^{\prime}+\gamma_{1}^{\prime} C R I M E_{i t}+\gamma_{2}^{\prime} L E V E R A G E_{i t}+\gamma_{3}^{\prime} S I Z E_{i t}+\gamma_{4}^{\prime} P B_{i t}+\varepsilon_{i t}
\end{aligned}
$$

2. The dependent variable in the first equation is the absolute value of the change in earnings scaled by lagged stock price. The dependent variable in the second model is the standard deviation of earnings scaled by total assets. The first equation includes fixed year and firm effects; the second equation includes one observation per firm.

3. Independent variables are:

a) CRIME - The magnitude of crime convictions in boards of directors and among senior executives. CRIME $=\{B O A R D, C E O, C F O\} . B O A R D$ is the proportion of board members convicted or suspected of crimes; $C E O(C F O)$ is an indicator variable taking the value of " 1 ", if the CEO (CFO) has been convicted/suspected of a crime, and " 0 " otherwise

b) LEVERAGE - Total interest-bearing debt divided by total assets

c) $S I Z E$ - Logarithm of total assets

d) $P B$ - Market value of equity divided by book value of equity).

4. All $t$-values are based on heteroskedasticity-adjusted standard errors. We also take into account the firm-level clustering in standard errors as in Petersen (2009).

5.,,$+++ *$ Significant at the $0.01,0.05$ and 0.10 levels, respectively. 
Table 6

Criminal Convictions and Goodwill Writeoffs

\begin{tabular}{|c|c|c|c|c|c|c|c|}
\hline \multirow[b]{2}{*}{ Variable } & \multirow{2}{*}{$\begin{array}{l}\text { Exp. } \\
\text { Sign }\end{array}$} & \multicolumn{2}{|c|}{ Board Members } & \multicolumn{2}{|c|}{ CEOs } & \multicolumn{2}{|c|}{ CFOs } \\
\hline & & LOGIT & TOBIT & LOGIT & TOBIT & LOGIT & TOBIT \\
\hline$R E T$ & - & $\begin{array}{l}-0.32 \\
(1.89)\end{array}$ & $\begin{array}{l}-0.08 \\
(2.59)\end{array}$ & $\begin{array}{l}-0.29 \\
(1.60)\end{array}$ & $\begin{array}{l}-0.08 \\
(2.40)\end{array}$ & $\begin{array}{l}-0.28 \\
(1.52)\end{array}$ & $\begin{array}{l}-0.08 \\
(2.30)\end{array}$ \\
\hline CRIME & + & $\begin{array}{c}1.69 \\
(12.98)++\end{array}$ & $\begin{array}{l}0.31 \\
(8.65)++\end{array}$ & $\begin{array}{c}0.37 \\
(4.28)+\end{array}$ & $\begin{array}{c}0.13 \\
(10.89)++\end{array}$ & $\begin{array}{c}0.01 \\
(0.01)\end{array}$ & $\begin{array}{l}-0.02 \\
(0.09)\end{array}$ \\
\hline CEOCHANGE & + & $\begin{array}{c}0.49 \\
(4.79)+\end{array}$ & $\begin{array}{l}0.10 \\
(3.91)+\end{array}$ & $\begin{array}{c}0.48 \\
(4.61)+\end{array}$ & $\begin{array}{c}0.10 \\
(3.63)^{*}\end{array}$ & $\begin{array}{c}0.48 \\
(4.71)+\end{array}$ & $\begin{array}{l}0.10 \\
(3.77)+\end{array}$ \\
\hline$R O A$ & - & $\begin{array}{l}-1.88 \\
(19.44)++\end{array}$ & $\begin{array}{c}-0.36 \\
(-12.93)++\end{array}$ & $\begin{array}{l}-1.91 \\
(20.21)++\end{array}$ & $\begin{array}{c}-0.36 \\
(-12.49)++\end{array}$ & $\begin{array}{l}-1.90 \\
(20.33)++\end{array}$ & $\begin{array}{c}-0.37 \\
(-13.26)++\end{array}$ \\
\hline SIZE & + & $\begin{array}{c}0.34 \\
(\mathbf{5 0 . 0 1})++\end{array}$ & $\begin{array}{c}\mathbf{0 . 0 7} \\
(\mathbf{3 3 . 4 0})++\end{array}$ & $\begin{array}{c}0.30 \\
(42.87)++\end{array}$ & $\begin{array}{c}0.06 \\
(29.96)++\end{array}$ & $\begin{array}{c}0.30 \\
(42.14)++\end{array}$ & $\begin{array}{c}0.06 \\
(29.38)++\end{array}$ \\
\hline LEVERAGE & - & $\begin{array}{l}-0.82 \\
(1.71)\end{array}$ & $\begin{array}{l}-0.15 \\
(1.19)\end{array}$ & $\begin{array}{l}-0.62 \\
(0.99)\end{array}$ & $\begin{array}{l}-0.13 \\
(0.95)\end{array}$ & $\begin{array}{l}-0.59 \\
(0.90)\end{array}$ & $\begin{array}{l}-0.11 \\
(0.70)\end{array}$ \\
\hline$P B$ & - & $\begin{array}{l}-0.16 \\
(7.50)++\end{array}$ & $\begin{array}{l}-0.03 \\
(5.50)+\end{array}$ & $\begin{array}{l}-0.16 \\
(8.08)++\end{array}$ & $\begin{array}{l}-0.03 \\
(6.35)+\end{array}$ & $\begin{array}{l}-0.16 \\
(7.90)++\end{array}$ & $\begin{array}{l}-0.03 \\
(5.280)+\end{array}$ \\
\hline $\begin{array}{l}\text { \# Writeoffs } \\
\text { Observations }\end{array}$ & & $\begin{array}{c}157 \\
1,754\end{array}$ & $\begin{array}{c}157 \\
1,754\end{array}$ & $\begin{array}{c}157 \\
1,754\end{array}$ & $\begin{array}{c}157 \\
1,754\end{array}$ & $\begin{array}{c}157 \\
1,754\end{array}$ & $\begin{array}{c}157 \\
1,754\end{array}$ \\
\hline
\end{tabular}

Notes:

1. The table presents results of estimating two models:

Logit:

$W O_{i t}=\delta_{0}+\delta_{1} R E T_{i t}+\delta_{2}$ CRIME $_{i t}+\delta_{3} C E O C H A N G E_{i t}+\delta_{4} R O A_{i t}+\delta_{5} S_{Z I Z E}+$

$\delta_{6} L E V E R A G E_{i t}+\delta_{7} P B_{i t}+v_{i t}$

Tobit:

WO / GOODWILL $L_{i t}=\phi_{0}+\phi_{1} R E T_{i t}+\phi_{2}$ CRIME $_{i t}+\phi_{3} C E O C H A N G E_{i t}+\phi_{4} R O A_{i t}+\phi_{5} S_{I Z E_{i t}}$

$+\phi_{6} L E V E R A G E_{i t}+\phi_{7} P B_{i t}+v_{i t}$

2. The dependent variable in the Logit model takes the value of " 1 " if the firm recognizes a goodwill writeoff and "0" otherwise. The dependent variable in the Tobit model is goodwill writeoff divided by the amount of goodwill before the writeoff (the proportion of goodwill that is written off).

3. Independent variables are: 
a) RET-Annual stock return

b) CRIME measures the magnitude of crime convictions in different parts of the corporations' governing bodies: 1) BOARD - the proportion of board members convicted or suspected of crimes; (2) $C E O$ - an indicator variable taking the value of "1", if the CEO has been convicted/suspected of a crime, and " 0 " otherwise; (3) CFO an indicator variable taking the value of "1", if the $C F O$ has been convicted/suspected of a crime, and " 0 " otherwise

c) CEOCHANGE - An indicator variable that obtains the value " 1 " if the $C E O$ has been replaced during the year, and " 0 " otherwise

d) $R O A$ - Return-to-asset-ratio

e) $S I Z E$ - Logarithm of total assets

f) LEVERAGE - Debt-to-asset-ratio

g) $P B$ - Price-to-book-ratio.

4.,,$+++ *$ Significant at the $0.01,0.05$ and 0.10 levels, respectively. 
Table 7

Changes in Directors and Senior Executives and the Likelihood of Goodwill Writeoffs

\begin{tabular}{|c|c|c|c|c|c|c|c|}
\hline Variable & $\begin{array}{l}\text { Exp. } \\
\text { Sign }\end{array}$ & $\begin{array}{c}\text { Board } \\
\text { Members }\end{array}$ & $\begin{array}{c}\text { Board } \\
\text { Members }\end{array}$ & CEOs & CEOs & CFOs & CFOs \\
\hline$R E T$ & - & $\begin{array}{l}-0.31 \\
(1.80)\end{array}$ & $\begin{array}{l}-0.34 \\
(2.06)\end{array}$ & $\begin{array}{l}-0.28 \\
(1.55)\end{array}$ & $\begin{array}{l}-0.29 \\
(1.65)\end{array}$ & $\begin{array}{c}-0.30 \\
1.70\end{array}$ & $\begin{array}{l}-0.30 \\
(1.69)\end{array}$ \\
\hline CRIME & + & & $\begin{array}{c}1.84 \\
(14.41)++\end{array}$ & & $\begin{array}{c}0.36 \\
(3.63)^{*}\end{array}$ & & $\begin{array}{c}0.03 \\
(0.01)\end{array}$ \\
\hline GOODCHANGE & + & $\begin{array}{c}0.62 \\
(4.87)+\end{array}$ & $\begin{array}{c}0.78 \\
(7.29)++\end{array}$ & $\begin{array}{c}0.69 \\
(2.76)^{*}\end{array}$ & $\begin{array}{c}0.82 \\
(3.77)^{*}\end{array}$ & $\begin{array}{c}0.06 \\
(0.01)\end{array}$ & $\begin{array}{c}0.43 \\
(0.41)\end{array}$ \\
\hline$B A D C H A N G E$ & + & $\begin{array}{c}0.33 \\
(1.44)\end{array}$ & $\begin{array}{c}0.18 \\
(0.42)\end{array}$ & $\begin{array}{c}0.73 \\
(3.71)^{*}\end{array}$ & $\begin{array}{c}0.49 \\
(1.57)\end{array}$ & $\begin{array}{c}0.09 \\
(0.02)\end{array}$ & $\begin{array}{l}-0.19 \\
(0.06)\end{array}$ \\
\hline$R O A$ & - & $\begin{array}{c}-1.89 \\
(19.99)++\end{array}$ & $\begin{array}{c}-1.92 \\
(19.85)++\end{array}$ & $\begin{array}{c}-1.96 \\
(21.75)++\end{array}$ & $\begin{array}{c}-1.97 \\
(21.58)++\end{array}$ & $\begin{array}{c}-1.95 \\
(21.68)++\end{array}$ & $\begin{array}{c}-1.95 \\
(21.52)++\end{array}$ \\
\hline SIZE & + & $\begin{array}{c}0.29 \\
(41.72)++\end{array}$ & $\begin{array}{c}0.34 \\
(49.17)++\end{array}$ & $\begin{array}{c}0.30 \\
(43.53)++\end{array}$ & $\begin{array}{c}0.30 \\
(43.37)++\end{array}$ & $\begin{array}{c}0.29 \\
(41.73)++\end{array}$ & $\begin{array}{c}0.29 \\
(70.79)++\end{array}$ \\
\hline LEVERAGE & - & $\begin{array}{l}-0.61 \\
(0.94)\end{array}$ & $\begin{array}{l}-0.83 \\
(1.74)\end{array}$ & $\begin{array}{c}-0.66 \\
(1.11)\end{array}$ & $\begin{array}{l}-0.68 \\
(1.16)\end{array}$ & $\begin{array}{l}-0.58 \\
(0.87)\end{array}$ & $\begin{array}{l}-0.60 \\
(0.92)\end{array}$ \\
\hline$P B$ & - & $\begin{array}{c}-0.16 \\
(7.82)++\end{array}$ & $\begin{array}{c}-0.15 \\
(7.41)++\end{array}$ & $\begin{array}{c}-0.16 \\
(7.65)++\end{array}$ & $\begin{array}{c}-0.16 \\
(7.73)++\end{array}$ & $\begin{array}{c}-0.16 \\
(7.95)++\end{array}$ & $\begin{array}{c}-0.16 \\
(7.98)++\end{array}$ \\
\hline $\begin{array}{l}\text { Number of "Good" changes } \\
\text { Number of "Bad" changes } \\
\text { Number of Writeoffs } \\
\text { Observations }\end{array}$ & & $\begin{array}{c}137 \\
199 \\
157 \\
1,754\end{array}$ & $\begin{array}{c}137 \\
199 \\
157 \\
1,754\end{array}$ & $\begin{array}{c}51 \\
61 \\
157 \\
1,754\end{array}$ & $\begin{array}{c}51 \\
61 \\
157 \\
1,754\end{array}$ & $\begin{array}{c}20 \\
26 \\
157 \\
1,754\end{array}$ & $\begin{array}{c}20 \\
26 \\
157 \\
1,754\end{array}$ \\
\hline
\end{tabular}

Notes:

1. The table presents results of estimating the following Logit model:

$$
\begin{aligned}
& W_{i t}=\delta_{0}+\delta_{1} R E T_{i t}+\delta_{2} \text { CRIME }_{i t}+\delta_{3}^{G} G O O D C H A N G E_{i t}+\delta_{3}^{B} B A D C H A N G E_{i t} \\
& +\delta_{4} R O A_{i t}+\delta_{5} S_{Z I Z} E_{i t}+\delta_{6} L_{E V E R A G E}+\delta_{7} P B_{i t}+v_{i t}
\end{aligned}
$$

2. We distinguish between two types of changes in directors and senior executives. For directors, a good change is defined as a decrease (increase) in the proportion of convicted board members from above (below) the sample median to below (above) the sample median. For CEOs and CFOs, a good (bad) change is replacing a convicted ("clean") $\mathrm{CEO} / \mathrm{CFO}$ in year $t-1$ with a "clean" (convicted) one in year $t$.

3. All regressions include year fixed-effects.

4. ++,,$+ *-$ Significant at the $0.01,0.05$ and 0.10 levels, respectively.

5. All the other variables are as in Table 6 . 
Table 8

Criminal Convictions and Conditional Conservatism*

\begin{tabular}{lcccc}
\hline Variable & $\begin{array}{l}\text { Exp. } \\
\text { Sign }\end{array}$ & $\begin{array}{c}\text { Board } \\
\text { Members }\end{array}$ & CEOs & CFOs \\
&
\end{tabular}

Panel A: Convicted/suspected directors and executives

\begin{tabular}{lcccc}
\hline RET & + & $\mathbf{0 . 0 7}$ & $\mathbf{0 . 1 1}$ & $\mathbf{0 . 0 7}$ \\
& & $(\mathbf{1 . 8 3})^{*}$ & $(\mathbf{4 . 5 9})++$ & $(\mathbf{1 . 6 7})^{*}$ \\
DRET & $?$ & -0.05 & 0.01 & 0.05 \\
& & $(-1.24)$ & $(0.50)$ & $(1.56)$ \\
RET $\times$ DRET & 0 & -0.02 & 0.11 & 0.16 \\
& & $(-0.19)$ & $(1.56)$ & $(1.64)$ \\
SIZE & + & $\mathbf{0 . 0 4}$ & $\mathbf{0 . 0 3}$ & $\mathbf{0 . 0 4}$ \\
& & $(\mathbf{3 . 9 8})++$ & $\mathbf{( 6 . 3 1 ) + +}$ & $\mathbf{( 3 . 9 8 4 ) + +}$ \\
LEVERAGE & - & $\mathbf{- 0 . 2 7}$ & $\mathbf{- 0 . 3 0}$ & -0.16 \\
& & $\mathbf{( - 2 . 1 1 ) +}$ & $\mathbf{( - 3 . 6 8 ) + +}$ & $(-1.36)$ \\
PB & $?$ & -0.01 & $\mathbf{- 0 . 0 1}$ & -0.01 \\
& & $(-0.16)$ & $\mathbf{( - 1 . 7 5})^{*}$ & $(-1.17)$ \\
Observations & & 330 & 602 & 291 \\
\hline
\end{tabular}

Panel B: Directors and executives not convicted/suspected

\begin{tabular}{lccll}
\hline RET & + & $\mathbf{0 . 0 6}$ & 0.03 & $\mathbf{0 . 0 6}$ \\
& & $(\mathbf{3 . 1 7})++$ & $(1.30)$ & $\mathbf{( 3 . 1 2 ) + +}$ \\
DRET & $?$ & 0.00 & -0.01 & -0.01 \\
& & $(0.17)$ & $(-0.97)$ & $(-1.12)$ \\
RET $\times$ DRET & + & $\mathbf{0 . 2 4}$ & $\mathbf{0 . 2 1}$ & $\mathbf{0 . 1 8}$ \\
& & $\mathbf{( 5 . 8 3 ) + +}$ & $\mathbf{( 4 . 5 2 ) + +}$ & $\mathbf{( 4 . 1 5 ) + +}$ \\
SIZE & + & $\mathbf{0 . 0 2}$ & $\mathbf{0 . 0 3}$ & $\mathbf{0 . 0 3}$ \\
& & $\mathbf{( 8 . 6 6 ) + +}$ & $\mathbf{( 7 . 3 4 ) + +}$ & $\mathbf{( 8 . 7 3 ) + +}$ \\
LEVERAGE & - & $\mathbf{- 0 . 0 7}$ & -0.05 & $\mathbf{- 0 . 1 3}$ \\
& & $\mathbf{( - 2 . 3 4 ) +}$ & $(-1.46)$ & $\mathbf{( - 3 . 2 3 ) + +}$ \\
PB & $?$ & $\mathbf{- 0 . 0 1}$ & $\mathbf{- 0 . 0 0}$ & $\mathbf{- 0 . 0 0}$ \\
& & $(-\mathbf{3 . 2 1})++$ & $\mathbf{( - 1 . 7 4 ) *}$ & $\mathbf{( - 1 . 9 5 ) *}$ \\
Observations & & 1,424 & 1,152 & 1,464 \\
\hline
\end{tabular}


*Notes:

1. The table presents results for Basu's (1997) regressions for conditional conservatism. The model is:

$$
\begin{aligned}
E P_{j t}= & \phi_{0}+\sum_{s=1999}^{2007} \phi_{s} Y E A R_{s}+\sum_{i=1}^{I} \phi_{i} \text { FIRM }_{i}+\phi_{1} R E T_{j t}+\phi_{2} D R E T_{j t}+\phi_{3} R E T_{j t} \times D_{R E T} \\
& +\phi_{8} S_{j t} E_{j t}+\phi_{9} L E V E R A G E_{j t}+\phi_{10} P B_{j t}+v_{j t}
\end{aligned}
$$

The dependent variable is the annual earnings per share divided by last year's stock price. Independent variables are defined as follows:
a. RET - Annual stock return
b. DRET - An indicator variable that obtains the value "1" if $R E T$ is negative, and "0" otherwise
c. SIZE - Logarithm of total assets
d. LEVERAGE $E_{i t}$ - Interest-bearing debt divided by total assets
e. $P B_{i t}-$ Market value of equity divided by book value of equity.

2. We estimate three regressions: (1) Companies in which more (less) than $50 \%$ of the directors have been convicted/suspected of a crime; (2) Companies in which the CEO has been convicted/suspected (not convicted/suspected) of a crime; and (3) Companies in which the CFO has been convicted/suspected (not convicted/suspected) of a crime.

3.,,$+++ *-$ Significant at the $0.01,0.05$ and 0.10 levels, respectively. 


\section{Appendix A - Legal and corporate governance systems in Sweden}

While the legal system in Sweden is based primarily on French and German civil codes, the importance of case law has increased over time (Strömholm, 1991). The penal code in Sweden is similar to that in other western countries, though penalties are often less severe in Sweden than in the US and the UK. Crime rates in Sweden are considered average among western countries (Dolmén, 2001). Leuz et al. (2003) give the Swedish law enforcement system a grade of 10 on a scale from zero to 10, based on scores developed by La Porta et al. (1998). Appendix B lists the crime convictions in our sample.

As a member of the European Union (EU), listed companies in Sweden must comply with EU directives regarding corporate governance as well as with the Swedish Corporate Governance Code, which is similar to the corporate governance rules and practices followed in the US. As in other western countries, the corporate governance system is made up of shareholders, who can exercise control over the firm through nomination committees and nonexecutive boards, executives in charge of operations, and external auditors (Unger, 2006).

The recent global integration of stock markets has resulted in a merger between the Stockholm Stock Exchange (OMX) and NASDAQ, forming the current OMX-NASDAQ as the main securities market in Sweden. The association between OMX and NASDAQ also upgraded the quality of corporate governance practices to those in the US. However, in contrast to the US, many large Swedish firms have major owners, who often take an active role in governing the company, which is likely to increase the level of corporate governance. Also, Swedish firms have employee representatives on the boards with the same rights and responsibilities as other directors elected by the shareholders. In addition, unlike the US, Sweden does not allow a CEO 
to be the chairman of the board. The Swedish Companies Act makes a clear distinction between the board and executive management, stating that the board is responsible for management, strategy and resource allocation, appointing, monitoring and evaluating the CEO, but less involved in operational decisions. The Companies Act requires a minimum of three directors on the board but stipulates no maximum. The Corporate Governance Code states that the majority of directors elected by the shareholders must be independent of the company and its senior management. Typically, only the CEO represents the executive management on the board; however, it is not uncommon to find Swedish listed firms without any senior executives on the board (Unger, 2006). At least two of the directors who are independent of the company and its management must also be independent of the company's major shareholders.

Potential candidates for the board are proposed by an independent nomination committee, and later elected by the shareholders at the shareholders' meeting. The nomination committee proposes candidates for the position of chairman and other members of the board, as well as remuneration for each director. The Swedish Corporate Governance Code requires that the majority of the nomination committee members are independent of the firm and its top management, and at least one member of the committee is independent of the largest shareholder in terms of voting power, or any ownership group. Board members may be members of the nomination committee but may not constitute a majority or chair the committee. The CEO and other senior executives cannot be members of the nomination committee (Unger, 2006). 


\section{Appendix B \\ Laws Violated by Board Members and Senior Executives}

\begin{tabular}{|c|c|c|c|c|}
\hline Code & Title & $\begin{array}{c}\text { \# of } \\
\text { convictions }\end{array}$ & Example & Maximum penalty \\
\hline 1951:649 & $\begin{array}{l}\text { Act on Criminal Responsibility for } \\
\text { Certain Traffic Offences }\end{array}$ & 285 & Drunken or reckless driving & 2 years in prison \\
\hline 1972:603 & Road Traffic Promulgation & 163 & $\begin{array}{l}\text { Various traffic-related crimes, all types of } \\
\text { vehicles }\end{array}$ & Fines \\
\hline 1998:1276 & Vehicle Ordinance & 134 & $\begin{array}{l}\text { Various traffic-related crimes, all kinds of } \\
\text { vehicles }\end{array}$ & Fines \\
\hline $1960: 418$ & $\begin{array}{l}\text { Act on Criminal Responsibility for } \\
\text { Smuggling }\end{array}$ & 97 & $\begin{array}{l}\text { Importing/exporting goods without proper } \\
\text { payment of duty or other taxes }\end{array}$ & 6 years in prison \\
\hline Ch. 8 & Theft, robbery, other stealing & 71 & Shoplifting, robbery & 10 years in prison \\
\hline $1972: 595$ & Vehicle Promulgation & 27 & Driving a car with a driving ban & Fines \\
\hline Ch. 3 & On Crimes against Life and Health & 30 & Assault, manslaughter & Life time in prison \\
\hline Ch. 9 & Fraud and Other Acts of Dishonesty & 22 & Fraud & 6 years in prison \\
\hline $1986: 300$ & Sea Traffic Ordinance & 22 & Violation of international sea traffic rules & Fines \\
\hline $1956: 617$ & Public Order Act & 18 & Arranging public meetings without permit & 6 months in prison \\
\hline Ch. 12 & Crimes Inflicting Damage & 15 & Damage to public property & 4 years in prison \\
\hline 1941:967 & The Conscription Act & 11 & Failure to appear for military service & 1 year in prison \\
\hline 1990:1342 & Insider Act & 11 & $\begin{array}{l}\text { Insider trading based on non-public } \\
\text { information }\end{array}$ & 2 years in prison \\
\hline $1971: 69$ & Tax Offence Act & 9 & $\begin{array}{l}\text { Incorrect information to tax authorities, } \\
\text { obstruction of tax control }\end{array}$ & 6 years in prison \\
\hline Ch. 4 & Crimes against Liberty and Peace & 9 & Unlawful coercion & Life in prison \\
\hline 1988:327 & Vehicle Tax Act & 7 & Driving a vehicle without paying vehicle tax & 6 months in prison \\
\hline Ch. 11 & Crime Against Creditors & 5 & Crime against creditors & 6 years in prison \\
\hline \multirow[t]{5}{*}{ Ch. 17} & Crime Against Public Activity & 6 & Obstruction of police & 8 years in prison \\
\hline & All other crimes & 164 & & \\
\hline & Total crime convictions & 1,106 & & \\
\hline & Suspected of crimes & 244 & & \\
\hline & Total convictions/suspicions & 1,350 & & \\
\hline
\end{tabular}

